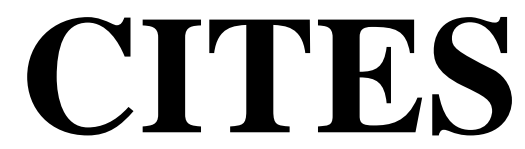

Decisions

\title{
Decisions of the
} Conference of the Parties to CITES in effect after the 13th meeting 



\section{Contents}

Contents

List of Decisions in effect (in numerical order) ............................................................ iii

List of acronyms and abbreviations ................................................................... vii

\section{Decision}

13.1

13.2 to 13.5

12.7 (Rev. CoP13)

$13.6 \& 13.7$

13.8

$13.9 \& 13.10$

13.11 to 13.17

$13.18 \& 13.19$

13.20

13.21

13.22

13.23 to 13.25

10.2 (Rev. CoP11)

13.26

11.57

13.27 to 13.35

$13.36 \& 13.37$

13.38 to 13.41

$13.42 \& 13.43$

13.44 to 13.47

$13.48 \& 13.49$

9.38 (Rev. CoP11)

13.50 to 13.53

13.54

13.55 to 13.59

13.60

13.61 to 13.65

12.72 (Rev. CoP13)

$\& 13.66$

\section{Subject}

Page

Strategic Vision 1

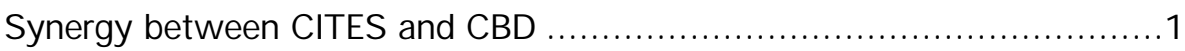

Cooperation with the Food and Agriculture Organization of the United Nations (FAO) .2

Addis A baba Principles and Guidelines for the Sustainable Use of

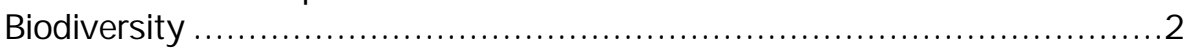

Global Strategy for Plant Conservation ..........................................

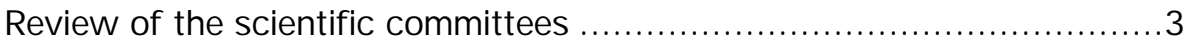

Improving regional communication and representation ........................3

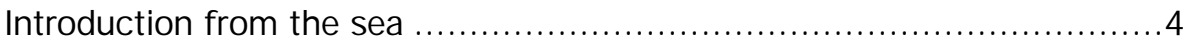

Trade in Appendix-I species ..................................................... 5

Species-specific Resolutions concerning Appendix-I species ................... 5

Conservation of and trade in Asian big cats .................................... 5

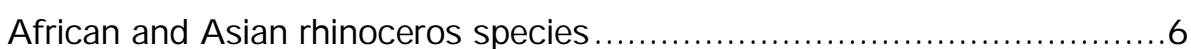

Elephants - Conditions for the disposal of ivory stocks and generating resources for conservation in African elephant range

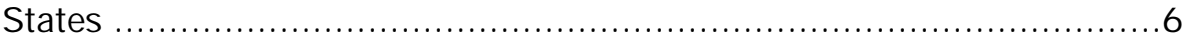

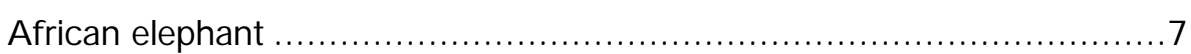

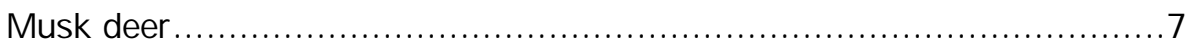

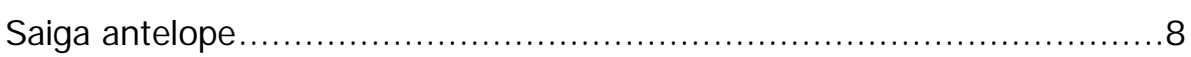

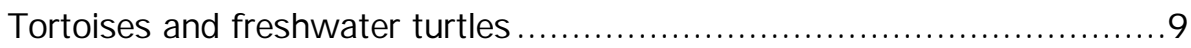

Haw ksbill turtle .......................................................... 10

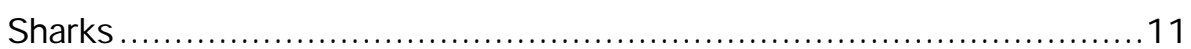

Conservation of and trade in sturgeon and paddlefish .......................12

Sea cucumbers ................................................................ 12

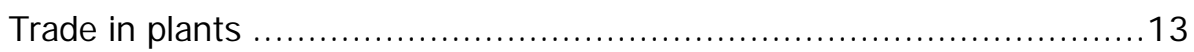

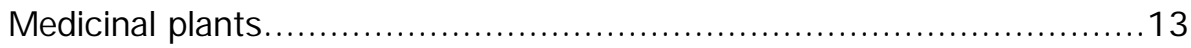

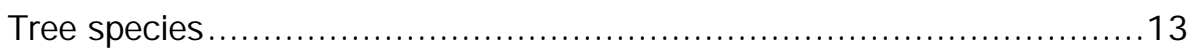

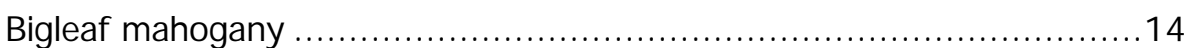

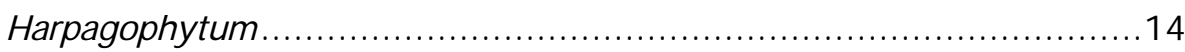

Agarw ood-producing taxa.........................................................

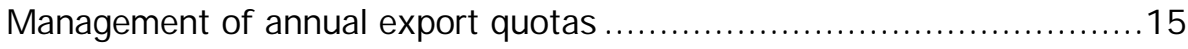


12.90 to $12.93 \quad$ Capacity-building programme for science-based establishment and implementation of voluntary national export quotas for A ppendix-II species ................................................................. 16

Review of Significant Trade. 16

13.68

Production systems for specimens of CITES-listed species 17

12.76

CITES permits and certificates

$13.69 \& 13.70$

13.71

Electronic permitting 18

Personal and household effects ................................................. 19

12.79

Non-commercial loan, donation or exchange of museum and herbarium specimens.... 19

$13.72 \& 13.73$

Artificially propagated plants 19

$13.74 \& 13.75$

National wildlife trade policy reviews. 19

$13.76 \& 13.77$

Further work on economic incentives 20

13.78

Relationship between ex situ production and in situ conservation......... 20

13.79 to 13.83

National laws for implementation of the Convention 21

13.84 to 13.87

Enforcement matters.....

Violations of the Convention by diplomats and troops serving under the flag of the United Nations....

Transport of live specimens.....

Reporting requirements

Review of the Appendices. 24

13.94

Standard nomenclature for birds. 24

13.95 to 13.97

Fossil corals. 25

$13.98 \& 13.99$

11.170

Annotation for Orchidaceae included in Appendix II ......................... 25

13.100

13.101 to 13.103 Implementation of the Quito Declaration. 25

Capacity building in the Oceanian region........................................ 26

Bushmeat.....

\section{Annexes}

Annex 1

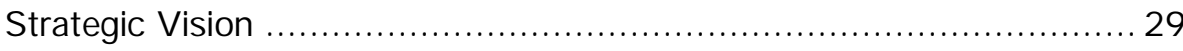

Action Plan......................................................................... 37

Annex 2

Action plan for the control of trade in African elephant ivory

Annex 3

Terms of reference for an evaluation of the Review of Significant Trade 


\section{List of Decisions in effect (in numerical order)}

Decision

9.15

9.38 (Rev. CoP11)

10.2 (Rev. CoP11)

11.57

11.170

12.7 (Rev. CoP13)

12.72 (Rev. CoP13)

12.76

12.79

12.90

12.91

12.92

12.93

13.1

13.2

13.3

13.4

13.5

13.6

13.7

13.8

13.9

13.10

13.11

13.12

13.13

13.14
Subject

Page

Violations of the Convention by diplomats and troops serving under the flag of the United Nations 23

Trade in plants

Elephants - Conditions for the disposal of ivory stocks and generating resources for conservation in African elephant range States..... 6

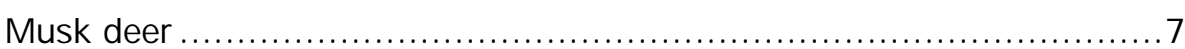

Implementation of the Quito Declaration 25

Cooperation with the Food and Agriculture Organization of the United Nations (FAO) 2

Management of annual export quotas ................................... 15

CITES permits and certificates ........................................ 18

Non-commercial loan, donation or exchange of museum and herbarium specimens

Capacity-building programme for science-based establishment and implementation of voluntary national export quotas for Appendix-II species

Capacity-building programme for science-based establishment and implementation of voluntary national export quotas for Appendix-II species

Capacity-building programme for science-based establishment and implementation of voluntary national export quotas for Appendix-II species

Capacity-building programme for science-based establishment and implementation of voluntary national export quotas for Appendix-II species

Strategic Vision 1

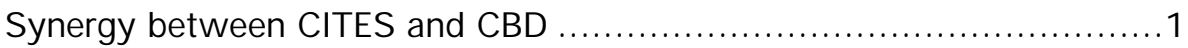

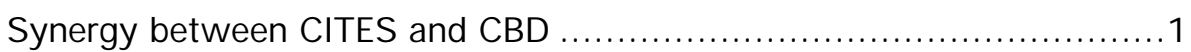

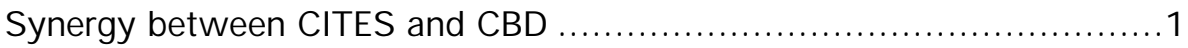

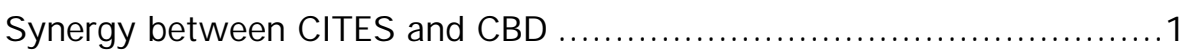

Addis Ababa Principles and Guidelines for the Sustainable Use of Biodiversity 2

Addis Ababa Principles and Guidelines for the Sustainable Use of Biodiversity

Global Strategy for Plant Conservation ................................... 3

Review of the scientific committees ...................................... 3

Review of the scientific committees ..................................... 3

Improving regional communication and representation ......................

Improving regional communication and representation .....................

Improving regional communication and representation ..................... 3

Improving regional communication and representation ...................... 3 
13.15

13.16

13.17

13.18

13.19

13.20

13.21

13.22

13.23

13.24

13.25

13.26

13.27

13.28

13.29

13.30

13.31

13.32

13.33

13.34

13.35

13.36

13.37

13.38

13.39

13.40

13.41

13.42

13.43

13.44

13.45

13.46

13.47

13.48

13.49

13.50

13.51

13.52

13.53

13.54

Improving regional communication and representation.

mproving regional communication and representation...................... 3

Improving regional communication and representation...................... 3

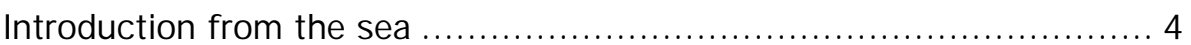

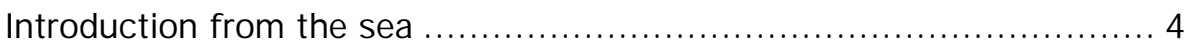

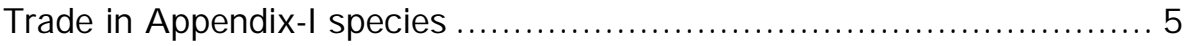

Species-specific Resolutions concerning Appendix-I species ................ 5

Conservation of and trade in Asian big cats .............................. 5

African and Asian rhinoceros species ..................................... 6

African and Asian rhinoceros species ..................................... 6

African and Asian rhinoceros species ...................................... 6

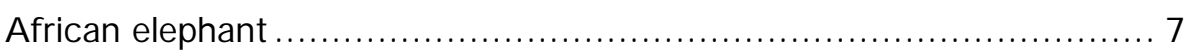

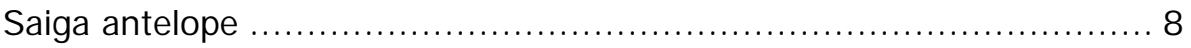

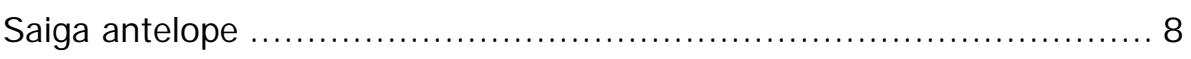

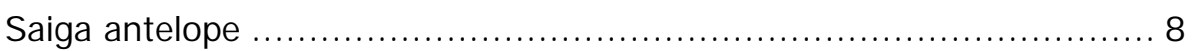

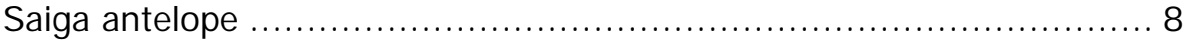

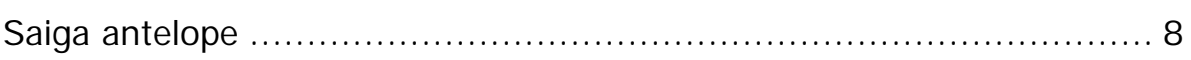

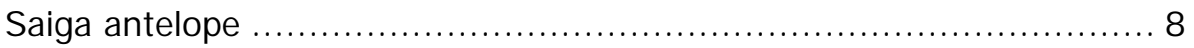

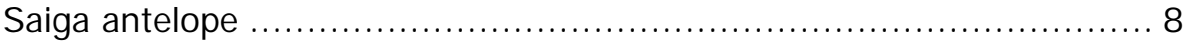

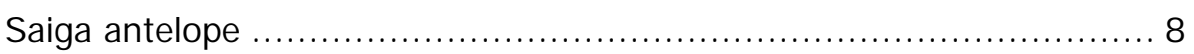

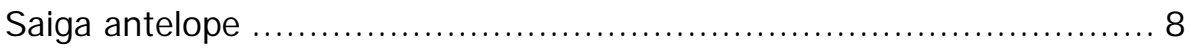

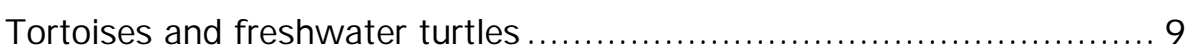

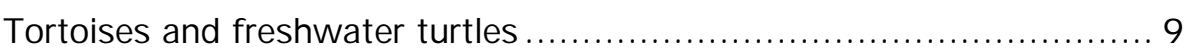

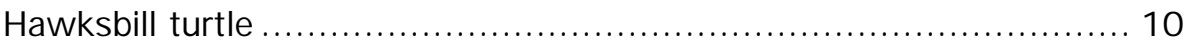

Haw ksbill turtle ........................................................... 10

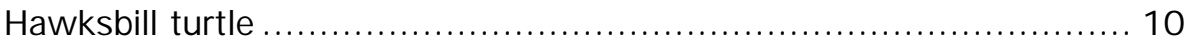

Haw ksbill turtle .......................................................... 10

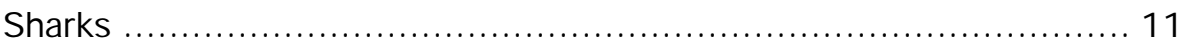

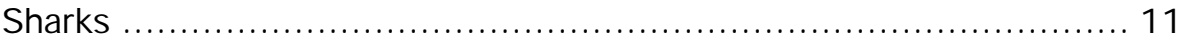

Conservation of and trade in sturgeon and paddlefish ................... 12

Conservation of and trade in sturgeon and paddlefish .................... 12

Conservation of and trade in sturgeon and paddlefish .................... 12

Conservation of and trade in sturgeon and paddlefish .................... 12

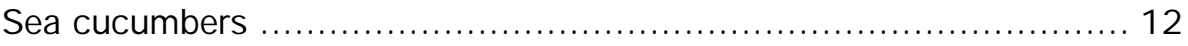

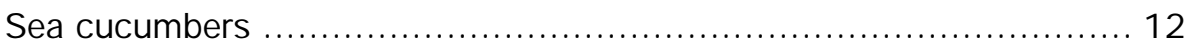

Medicinal plants ....................................................... 13

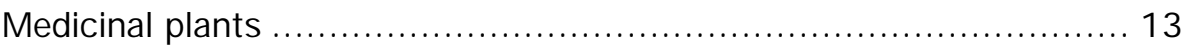

Medicinal plants ......................................................... 13

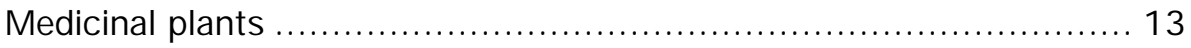

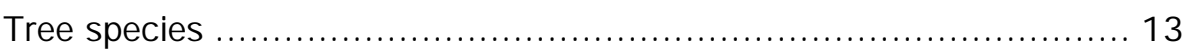


13.55

13.56

13.57

13.58

13.59

13.60

13.61

13.62

13.63

13.64

13.65

13.66

13.67

13.68

13.69

13.70

13.71

13.72

13.73

13.74

13.75

13.76

13.77

13.78

13.79

13.80

13.81

13.82

13.83

13.84

13.85

13.86

13.87

13.88

13.89

13.90

13.91

13.92

13.93

13.94

Bigleaf mahogany

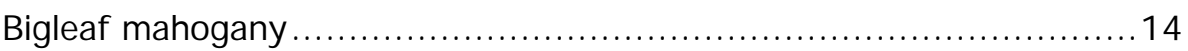

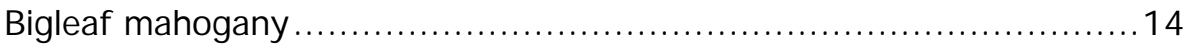

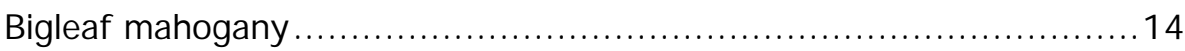

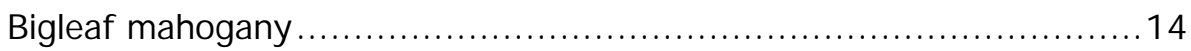

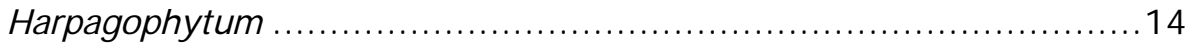

Agarw ood-producing taxa .............................................. 15

A garw ood-producing taxa ................................................. 15

Agarw ood-producing taxa ............................................... 15

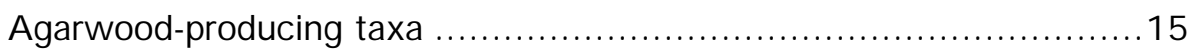

Agarw ood-producing taxa .............................................. 15

Management of annual export quotas ..................................... 15

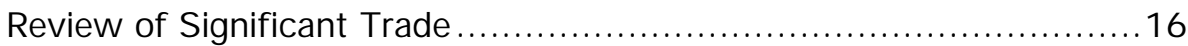

Production systems for specimens of CITES-listed species ...............17

Electronic permitting ....................................................... 18

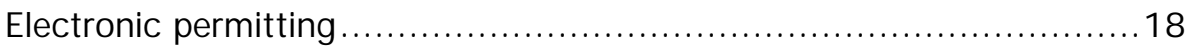

Personal and household effects ...................................... 19

Artificially propagated plants ........................................... 19

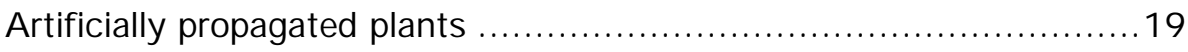

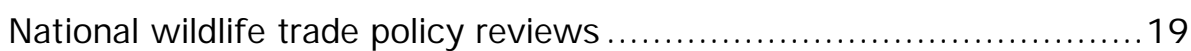

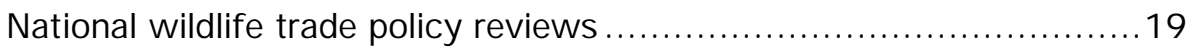

Further work on economic incentives..................................20

Further work on economic incentives....................................20

Relationship between ex situ production and in situ conservation.......20

National laws for implementation of the Convention .......................21

National laws for implementation of the Convention ..................... 21

National laws for implementation of the Convention .......................21

National laws for implementation of the Convention ......................21

National laws for implementation of the Convention ...................... 21

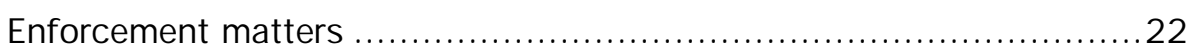

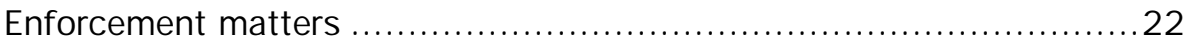

Enforcement matters ....................................................... 22

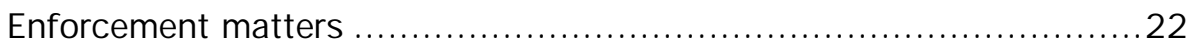

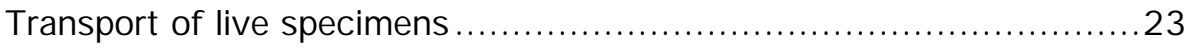

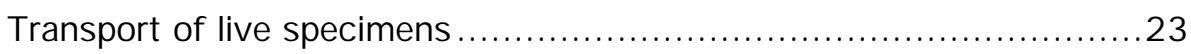

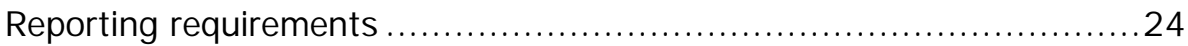

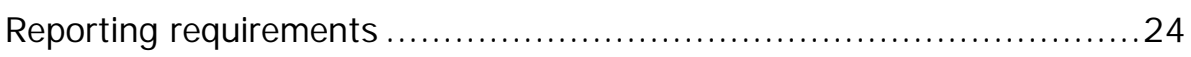

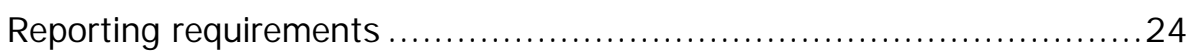

Review of the Appendices ............................................. 24

Standard nomenclature for birds .......................................... 24 
Fossil corals

Fossil corals....

Fossil corals 25

13.98

Annotation for Orchidaceae included in A ppendix II 25

13.99

A nnotation for Orchidaceae included in Appendix II 25

13.100

Capacity building in the Oceanian region 26

13.101

Bushmeat 26

13.102

Bushmeat 26

13.103

Bushmeat 26

13.104

Master's course on Management, Access and Conservation of Species in Trade.

13.105

Master's course on Management, Access and Conservation of Species in Trade. 


\section{List of acronyms and abbreviations}

CITES

CBD

CCAMLR

CMS

COFI

FAO

GATT

GEF

GSPC

IATA

ICPO-Interpol

IPOA-Sharks

IUCN

MEA

$\mathrm{MOU}$

TRAFFIC

UNEP

UNEP/ROLAC

UNEP-WCMC

WCO

WTO
Convention on International Trade in Endangered Species of Wild Fauna and Flora

Convention on Biological Diversity

Commission for the Conservation of Antarctic Marine Living Resources

Convention on Migratory Species of Wild Animals

Committee on Fisheries (of FAO)

Food and Agriculture Organization of the United Nations

General Agreement on Tariffs and Trade

Global Environment Facility

Global Strategy for Plant Conservation

International Air Transport Association

International Criminal Police Organization

International Plan of Action for the Conservation and Management of Sharks

The World Conservation Union

Multilateral Environmental Agreement

Memorandum of Understanding

Trade Records Analysis of Flora and Fauna in Commerce

United Nations Environment Programme

UNEP Regional Office for Latin America and the Caribbean

UNEP World Conservation Monitoring Centre

World Customs Organization

World Trade Organization 



\section{Strategic Vision}

13.1 The Conference of the Parties decides:

a) to extend until the end of 2007 the time validity of the Strategic Vision and its Action Plan, which were adopted with Decision 11.1 at its 11th meeting (Gigiri, 2000) (attached as Annex 1 to these Decisions);

b) to establish a Strategic Plan Working Group as a subcommittee of the Standing Committee, with representation from all regions and of the Animals and Plants Committees, with the task to develop, with the cooperation of the Secretariat, a proposal for a Strategic Vision and Action Plan through 2013, in particular in order to contribute to the achievement of the World Summit on Sustainable Development (WSSD) targets of significantly reducing the rate of biodiversity loss by 2010;

c) to invite input from relevant intergovernmental organizations to the work of the Strategic Plan Working Group with respect to possible synergies;

d) to urge all Parties and to instruct the Secretariat and the permanent Committees to evaluate their efforts in relation to the implementation of the existing Strategic Vision and Action Plan and to submit the outcome thereof to the Strategic Plan Working Group through their representatives on that working group;

e) that the Strategic Plan Working Group shall submit its proposal to the Standing Committee for approval at its annual meeting prior to the deadline for the submission of proposals for consideration at the 14th meeting of the Conference of the Parties, which is to be held in 2007; and

f) that the Standing Committee shall submit the proposal for a Strategic Vision and Action Plan through 2013 for adoption at the 14th meeting of the Conference of the Parties.

\section{Synergy between CITES and CBD}

\section{Directed to the Standing Committee}

13.2 The Standing Committee, at its 53rd meeting, shall:

a) consider the findings and recommendations of the Vilm report, taking into account the Secretariat's conclusions (referred to in Decision 13.5), and any comments by the Parties, and identify possible priority actions to improve synergies between the two Conventions in areas of common concern in order to contribute to reaching the WSSD 2010 target, considering inter alia Sustainable Use, the Ecosystem Approach and Access and Benefit Sharing ${ }^{1}$; and

b) provide guidance, on that basis, to the Standing Committee's Strategic Plan Working Group on the items to be considered in the revision of the Strategic Vision and Action Plan.

13.3 Following its discussions on the outcomes of the Vilm report, the Standing Committee shall provide guidance to the Secretariat so as to revise, in conjunction with the CBD Secretariat, the Work Plan for Implementation of J oint Activities attached to the Memorandum of Cooperation between them, before the 14th meeting of the Conference of the Parties.

1 Terminology as used in the Vilm report. 


\section{Directed to the Secretariat}

13.4 The Secretariat shall, in collaboration with the Chairmen of the Animals and Plants Committees, review the findings and recommendations of the Vilm report in order to identify its most relevant aspects.

13.5 The Secretariat shall make its conclusions available to the Parties at least 90 days before the 53rd meeting of the Standing Committee, in order to enable Parties to submit comments for consideration by the Standing Committee.

\section{Cooperation with the Food and Agriculture Organization of the United Nations (FAO)}

\section{Directed to the Standing Committee}

12.7 On the basis of the recognition by the Conference of the Parties of the primary role of (Rev. FAO and regional fisheries management organizations in fisheries management and the CoP13) role of CITES in regulating international trade, the Standing Committee shall work with FAO in the drafting of a Memorandum of Understanding (MOU) between CITES and FAO, to establish a framew ork for cooperation.

The following terms of reference should guide the Standing Committee in carrying out this work:

a) elaborate provisions regarding future FAO involvement in the scientific evaluation of proposals for including exploited aquatic species in the Appendices or for dow nlisting them (see A ppendix F of the Report of COFI: FTVIII);

b) cooperate with respect to capacity building in developing countries, in particular efforts centred on fisheries law enforcement activities of mutual interest;

c) append to the MoU annexes consisting of workplans listing issues of common interest to both organizations, including those found in Appendix F of the Report of COFI: FTVIII; and

d) report on work completed under the $\mathrm{MoU}$ at each meeting of the Conference of the Parties to CITES and the FAO Committee on Fisheries.

\section{Addis Ababa Principles and Guidelines for the Sustainable Use of Biodiversity}

\section{Directed to the Animals and Plants Committees}

13.6 The Animals and Plants Committees shall identify those principles and guidelines of most relevance to CITES, taking account of case studies provided by the Parties on how these could be used in specific cases of exports of specimens of Appendix-II species, and report at the 14th meeting of the Conference of the Parties.

\section{Directed to the Secretariat}

\subsection{The Secretariat shall:}

a) distribute the Addis Ababa Principles and Guidelines for the Sustainable Use of Biodiversity to all CITES Management and Scientific Authorities; 
b) invite the Parties to provide the Animals and Plants Committees with case studies of how these Principles and Guidelines could be used in specific cases of exports of specimens of Appendix-II species;

c) incorporate consideration of these Principles and Guidelines into its work plan, with reference to CITES non-detriment findings and capacity building, in particular for Scientific Authorities; and

d) following completion of the work of the Animals and Plants Committees, and in cooperation with the Chairmen of the Animals and Plants Committees, incorporate relevant principles and guidelines as identified by those Committees into its capacity-building programme for Scientific Authorities.

\section{Global Strategy for Plant Conservation}

\section{Directed to the Plants Committee}

13.8 The Plants Committee shall link its activities and collaborations with the CBD Global Strategy for Plant Conservation (GSPC), especially regarding target XI 'No species of wild flora endangered by international trade', and with other CBD-related issues.

\section{Review of the scientific committees}

\section{Directed to the Animals, Plants and Nomenclature Committees}

13.9 The Animals, Plants and Nomenclature Committees shall draft terms of reference for a review, with the objective of improving and facilitating the performance of their functions. The Committees shall submit the draft terms of reference before the end of 2005 to the Standing Committee.

\section{Directed to the Standing Committee}

13.10 The Standing Committee shall determine a process for the review and proceed with the review based on the terms of reference produced by the scientific committees and report at the 14th meeting of the Conference of the Parties.

\section{Improving regional communication and representation}

\section{Directed to Parties}

13.11 The Parties shall provide to the Secretariat by 1 A pril 2005 a contact focal point for the Animals, Plants and Nomenclature Committees, including email, telephone and fax details. This information will be available on the CITES w ebsite.

\section{Directed to the Animals, Plants and Nomenclature Committees}

13.12 The Animals, Plants and Nomenclature Committees shall review at their meetings the conditions under which their members and alternate members perform their duties to ensure continuity and effective regional representation, and report their findings to the Standing Committee.

13.13 The Plants and Animals Committees shall form a joint email working group comprising two representatives of each Committee and an appointed chairman to develop a 
manual for regional representatives in 2005 that explains the roles and duties of the representatives, provides practical advice on how to accomplish the mandate, is applicable under different cultural conditions, and contains information for the Management and Scientific Authorities of Parties to explain the role and duties of regional representatives, and the relevant obligations by Parties towards regional representatives. External funding is to be sought for printing of the manual.

\section{Directed to the Secretariat}

13.14 The Secretariat shall ensure that any vacancies in the Animals, Plants and Nomenclature Committees are brought immediately to the attention of the Standing Committee, in order to fill the vacancies as soon as possible.

13.15 The Secretariat shall publish on the CITES website forthcoming deadlines relevant to the work of the Animals, Plants and Nomenclature Committees.

13.16 The Secretariat shall explore funding options to ensure that the regional representatives to the Animals and Plants Committees and the Co-Chairmen of the Nomenclature Committee from developing countries and countries with economies in transition can attend the meetings of the Conference of the Parties and fully participate in the committee work.

13.17 The Secretariat shall look for funding to support the holding of regional meetings in association with regional seminars or other related meetings organized by the Secretariat. The regional representatives should prepare the agenda and chair the meeting.

\section{Introduction from the sea}

\section{Directed to the Standing Committee}

\subsection{The Standing Committee shall:}

a) contingent on the availability of external funding obtained in accordance with Decision 13.19, convene a workshop on introduction from the sea to consider implementation and technical issues, taking into account the two Expert Consultations of the Food and Agriculture Organization of the United Nations (FAO) on implementation and legal issues ${ }^{1}$, and documents and discussions that occurred at the 11th and 13th meetings of the Conference of the Parties on these issues;

b) invite the following participants to the workshop: three representatives from each CITES region to represent a Management Authority, a Scientific Authority, and a fisheries expert; two representatives from FAO; a representative from WCO; and two representatives of NGOs or IGOs with CITES and fisheries expertise;

c) through its clearing-house mechanism, decide on the appropriate way to handle the logistics, agenda and reporting for the workshop and set timelines for the work to be done;

d) ask the Secretariat to provide the report and recommendations from the workshop to the Parties through a notification and to FAO for consideration and comment; and

1 FAO Fisheries Report No. 741: Report of the expert consultation on implementation issues associated with listing commercially-exploited aquatic species on CITES Appendices, and FAO Fisheries Report No. 746: Report of the expert consultation on legal issues related to CITES and commercially-exploited aquatic species. 
e) consider the comments received on the workshop report from the Parties and FAO, and ask the Secretariat to prepare a discussion paper and draft resolution for consideration by the Standing Committee before submitting the draft resolution for consideration at the 14th meeting of the Conference of the Parties.

\section{Directed to the Secretariat}

13.19 The Secretariat shall:

a) as a matter of high priority, assist in obtaining funds from interested Parties, intergovernmental and non-governmental organizations, and other funding sources to support a workshop on introduction from the sea under the terms of reference set out in Decision 13.18;

b) assist the Standing Committee in preparing for the workshop; and

c) welcome the consultations convened by FAO and approach the FAO Secretariat concerning further collaboration on introduction from the sea.

\section{Trade in Appendix-I species}

\section{Directed to the Standing Committee}

13.20 The Standing Committee shall:

a) conduct a review of trade in Appendix-I plant and animal species, through UNEPWCMC. The review should take into account all exports, re-exports, and imports of Appendix-I specimens, including the species name, the source and purpose codes, existing exemptions and all other relevant information for the last five years. The identity of individual Parties should be protected in the report; and

b) consider the UNEP-WCMC report and draft recommendations, if necessary, based on the analysis of Appendix-I trade, at its 54th meeting, and present these recommendations for consideration at the 14th meeting of the Conference of the Parties.

\section{Species-specific Resolutions concerning Appendix-I species}

\section{Directed to the Secretariat}

13.21 The Secretariat shall, in consultation with the Standing Committee, examine all speciesspecific Resolutions concerning Appendix-I species with a view to preparing a consolidated resolution concerning the enforcement of trade controls for all Appendix-I species for consideration at the 14th meeting of the Conference of the Parties.

\section{Conservation of and trade in Asian big cats}

\section{Directed to the Secretariat}

13.22 The Secretariat shall seek external funding to enable it to convene a meeting of relevant members of the CITES Tiger Enforcement Task Force to examine, in particular, the issue of illicit trade in Asian big cat skins with a view to facilitating and improving the exchange of enforcement information and the coordination of investigations. 


\section{African and Asian rhinoceros species}

\section{Directed to Parties}

13.23 Range States of African and Asian rhinoceros species are encouraged to support the IUCN/SSC African and Asian Rhinoceros Specialist Groups in collecting and collating the information referred to in Decision 13.25.

13.24 Understanding that the IUCN/SSC African and Asian Rhinoceros Specialist Groups operate on a voluntary basis and may be constrained by a lack of resources, Parties and other donors are urged to provide support to these groups for undertaking these activities.

\section{Directed to the Secretariat}

\subsection{The Secretariat shall:}

a) invite the IUCN/SSC African and Asian Rhinoceros Specialist Groups to share information on the national and continental conservation status of African and Asian rhinoceros species, the legal and illegal trade in rhinoceros specimens, incidents of illegal killing of rhinoceros, and conservation and management strategies and actions; and

b) submit a written summary of the information for consideration at the 14th meeting of the Conference of the Parties that will include recommendations for further reporting on the conservation of and trade in African and Asian rhinoceroses.

\section{Elephants - Conditions for the disposal of ivory stocks and generating resources for conservation in African elephant range States}

10.2

(Rev.

CoP11) a) The African elephant range States recognize:

i) the threats that stockpiles pose to sustainable legal trade;

ii) that stockpiles are a vital economic resource for them;

iii) that various funding commitments were made by donor countries and agencies to offset the loss of assets in the interest of unifying these States regarding the inclusion of African elephant populations in Appendix I;

iv) the significance of channelling such assets from ivory into improving conservation and community-based conservation and development programmes;

v) the failure of donors to fund elephant conservation action plans draw $n$ up by the range States at the urging of donor countries and conservation organizations; and

vi) that, at its ninth meeting, the Conference of the Parties directed the Standing Committee to review the issue of stockpiles and to report back at the 10th meeting.

b) Accordingly, the African elephant range States agree that all revenues from any purchase of stockpiles by donor countries and organizations will be deposited in and managed through conservation trust funds, and that:

i) such funds shall be managed by Boards of Trustees (such as representatives of Governments, donors, the CITES Secretariat, etc.) set up, as appropriate, in each range State, which would direct the proceeds into enhanced 
conservation, monitoring, capacity building and local community-based programmes; and

ii) these funds must have a positive rather than harmful influence on elephant conservation.

c) It is understood that this decision provides for a one-off purchase for noncommercial purposes of government stocks declared by African elephant range States to the CITES Secretariat within the 90-day period before the transfer to Appendix II of certain populations of the African elephant takes effect. The ivory stocks declared should be marked in accordance with the ivory marking system approved by the Conference of the Parties in Resolution Conf. 10.10 (Rev. CoP12 ${ }^{1}$ ). In addition, the source of ivory stocks should be given. The stocks of ivory should be consolidated in a pre-determined number of locations. An independent audit of any declared stocks shall be undertaken under the auspices of TRAFFIC International, in cooperation with the CITES Secretariat.

d) The African elephant range States that have not yet been able to register their ivory stocks and develop adequate controls over ivory stocks require priority assistance from donor countries to establish a level of conservation management conducive to the long-term survival of the African elephant.

e) The African elephant range States therefore urge that this matter be acted upon urgently since any delays will result in illegal trade and the premature opening of ivory trade in non-proponent range States.

f) This mechanism only applies to those range States wishing to dispose of ivory stocks and agreeing to and participating in:

i) an international system for reporting and monitoring legal and illegal international trade, through an international database in the CITES Secretariat and TRAFFIC International; and

ii) an international system for reporting and monitoring illegal trade and illegal hunting within or between elephant range States, through an international database in the CITES Secretariat, with support from TRAFFIC International and institutions such as the IUCN/SSC African Elephant Specialist Group and the Lusaka Agreement.

\section{African elephant}

13.26 The Conference of the Parties adopted the Action plan for the control of trade in African elephant ivory attached as Annex 2 to these Decisions.

\section{Musk deer}

\section{Directed to Parties}

11.57 Parties that authorize export of raw musk should consider reductions in their export quotas, if biologically appropriate, until the Animals Committee has completed its consideration of musk deer in the Review of Significant Trade.

\footnotetext{
1 Corrected by the Secretariat: formerly referred to Resolution Conf. 10.10 (Rev.).
} 


\section{Saiga antelope}

\section{Directed to Parties and others}

13.27 Important consumer and trading countries of saiga parts and derivatives [as identified by the Secretariat pursuant to Decision 13.35, paragraph g)] should report to the Secretariat, for transmission to each meeting of the Standing Committee betw een its 53rd meeting and the 14th meeting of the Conference of the Parties, and in their biennial reports on:
a) stockpiles in their country; and
b) steps they are taking to control any legal and illegal trade in parts and derivatives of the saiga antelope.

13.28 Donor Parties, aid agencies, businesses using and producing saiga products, intergovernmental organizations and non-governmental organizations are urged to assist all range States and consumer countries in any way possible with the conservation of this species, including:
a) the provision of funding;
b) the provision of assistance with enforcement, anti-poaching and anti-smuggling;
c) the provision of capacity building;
d) the provision of equipment, particularly for undertaking anti-poaching and anti- smuggling activities;
e) the provision of assistance with education and public aw areness;
f) the provision of assistance with population monitoring;
g) analysis and monitoring of stockpiles in key consumer countries;
h) gathering and exchange of scientific, technical and legal information and expertise; and
i) supporting missions of the Secretariat, as specified in Decision 13.35, paragraph c).

\section{Directed to all range States of Saiga tatarica \\ (Kazakhstan, Mongolia, Russian Federation, Turkmenistan, Uzbekistan)}

13.29 All relevant range States are urged to complete their internal consultations and processes, making the necessary arrangements with the Secretariat of the Convention on Migratory Species (CMS), to sign as soon as practicable the 'Memorandum of Understanding concerning Conservation, Restoration and Sustainable Use of the Saiga Antelope (Saiga tatarica tatarica)' drafted at the workshop in Elista, Kalmykia, in May 2002, and to implement the Saiga Action Plan in order to restore the habitat and populations of the saiga antelope, and enhance transboundary and international cooperation through inter alia a regional conservation and management strategy.

13.30 Mongolia is urged to participate in the implementation of those elements of the Saiga Action Plan that are of relevance to the conservation of its saiga population.

13.31 All saiga range States should address the problems they have in implementing CITES and ensure the conservation and management of Saiga tatarica in close cooperation with the Secretariat, other countries, other competent authorities, intergovernmental organizations, and non-governmental organizations.

13.32 Recognizing that there is uncertainty as to the occurrence of Saiga tatarica in China, China is encouraged to investigate and report on the status of the wild population of 
Saiga tatarica and its habitats in China, and undertake any necessary conservation activities.

13.33 All range States should report on the activities outlined above, through the Secretariat, to the Standing Committee at each of its meetings between its 53rd meeting and the 14 th meeting of the Conference of the Parties.

\section{Directed to the Standing Committee}

13.34 The Standing Committee shall discuss the conservation of and trade in Saiga tatarica at its meetings between its 53rd meeting and the 14th meeting of the Conference of the Parties and recommend appropriate action.

\section{Directed to the Secretariat}

\subsection{The Secretariat shall:}

a) assist the Parties with the implementation of the CITES-relevant aspects of the Saiga Action Plan of the Memorandum of Understanding Concerning Conservation, Restoration and Sustainable Use of the Saiga Antelope;

b) facilitate technical and other assistance, as required, and work with all range and consumer countries as appropriate on trade-related aspects of the conservation of saiga, with particular focus on China, Kazakhstan and the Russian Federation;

c) undertake missions to range and consumer Parties to verify, among other things, species conservation and management efforts, enforcement actions, stockpiles of saiga specimens, implementation of the Saiga Action Plan and compliance with recommendations of the Standing Committee;

d) include the issue of saiga trade and conservation in an enforcement workshop in the Asian region to be held before the 14th meeting of the Conference of the Parties;

e) cooperate with the Secretariat of the Convention on Migratory Species (CMS) on issues pertaining to saiga including, but not limited to, the implementation of the Saiga Action Plan and the Memorandum of Understanding between the two conventions;

f) if requested, assist the range States in meeting the reporting requirements referred to in Decision 13.33;

g) identify important consumer and trading countries of saiga parts and derivatives, and encourage them to take the actions required under Decision 13.27; and

h) report on progress in implementation of the Decisions regarding Saiga tatarica to the Standing Committee at each of its meetings between its 53 rd meeting and the 14th meeting of the Conference of the Parties, as w ell as at the latter meeting.

\section{Tortoises and freshwater turtles}

\section{Directed to the Secretariat}

13.36 The Secretariat shall submit a written summary of the information on the implementation of Resolution Conf. 11.9 (Rev. CoP13) that is contained in biennial reports from Parties for consideration at the 14th meeting of the Conference of the Parties. 


\subsection{The Secretariat shall:}

a) liaise with the World Customs Organization to promote the establishment and use of specific headings within the standard tariff classifications of the Harmonized System for tortoises and freshwater turtles and for products thereof;

b) ensure that the proceedings of the technical workshop on conservation of and trade in tortoises and freshwater turtles (Kunming, March 2002) are made available to the general public via the CITES website; and

c) report on these activities at the 14th meeting of the Conference of the Parties.

\section{Hawksbill turtle}

\section{Directed to Parties}

13.38 States and territories in the wider Caribbean region should:

a) develop further a collaborative regional conservation strategy, based on the outline of a strategic plan provided in the Annex to document CoP12 Doc. 20.2 Annex 4, to enhance the conservation status of the haw ksbill turtle and, where appropriate, other marine turtles within the wider Caribbean;

b) implement the strategy in collaboration with multilateral environmental agreements and intergovernmental organizations active in the region or on the conservation and sustainable use of the species and through the development and implementation of national management plans;

c) adopt and implement standard protocols for the monitoring, at recommended and agreed index sites, of populations of nesting and foraging hawksbill turtles and make efforts to monitor legal harvests, by-catch in other fisheries and illegal take;

d) implement measures to reduce illegal catch and illegal trade in haw ksbill turtles and parts and derivatives thereof, including measures to improve the control of stocks of hawksbill turtle parts and derivatives by identifying, marking, registering and securing all such stockpiles; and

e) report to the Secretariat on progress $w$ ith the implementation of the regional conservation strategy and national management plans at least six months before the 14th meeting of the Conference of the Parties.

\section{Directed to Parties, intergovernmental organizations, international aid agencies and non-governmental organizations}

13.39 Governments and intergovernmental organizations, international aid agencies and nongovernmental organizations are encouraged to provide funds to enable the implementation of the Caribbean regional haw ksbill strategy and to support the regional dialogue process.

\section{Directed to the Secretariat}

13.40 The Secretariat shall, subject to funding and before the 14th meeting of the Conference of the Parties, arrange at least one meeting of the wider Caribbean region on the hawksbill turtle in order to facilitate regional collaboration, planning and information exchange, as well as collaboration with other bodies and multilateral agreements with a mandate concerning the conservation and management of this species in the wider Caribbean region. 
13.41 The Secretariat shall collate reports received from States and territories in the wider Caribbean region on progress with the implementation of the regional conservation strategy and national management plans and present a written summary at the 14 th meeting of the Conference of the Parties.

\section{Sharks}

\section{Directed to Parties}

13.42 Parties:

a) should request, through their delegations to the 26th meeting of the Committee on Fisheries (COFI) of the Food and Agriculture Organization of the United Nations (FAO) that FAO consider convening a workshop or consultation on the conservation and management of sharks, in time for output to be considered at the 14th meeting of the Conference of the Parties, inter alia to:

i) consider and review progress with the implementation of the IPOA-Sharks; and

ii) assess the effectiveness and efficiency of current conservation and management measures for sharks and identify any improvements needed;

b) are encouraged to improve their data collection and reporting to FAO of catches and landings of and trade in sharks, at the species level where possible, recognizing that inter alia this may be a first step towards the development and implementation of Shark Assessment Reports and National Plans of Action or other relevant national instruments;

c) that require assistance to build capacity to manage their shark fisheries are encouraged to seek such assistance from FAO or other appropriate organizations; and

d) should take note of the species-specific recommendations in document CoP13 Doc. 35 Annex 2 with a view to ensuring that international trade is not detrimental to the status of these species.

\section{Directed to the Animals Committee}

13.43 The Animals Committee, taking account of the work of the Food and Agriculture Organization of the United Nations (FAO) on the conservation and management of sharks and on CITES implementation issues relating to listed marine species, shall:

a) review implementation issues related to sharks listed in the CITES Appendices with a view inter alia to sharing experiences that may have arisen and solutions that may have been found;

b) identify specific cases where trade is having an adverse impact on sharks, in particular those key shark species threatened in this way;

c) prepare a report on trade-related measures adopted and implemented by Parties that are aimed at improving the conservation status of sharks; and

d) report on the above at the 14th meeting of the Conference of Parties. 


\section{Conservation of and trade in sturgeon and paddlefish}

\section{Directed to Parties}

13.44 In consultation with the CITES Secretariat and relevant experts, interested Parties should undertake an assessment of the technical and legal feasibility to establish a database concerning trade in sturgeon specimens subject to annual quotas as outlined in Resolution Conf. 12.7 (Rev. CoP13). This database would be updated regularly and could include, pending needs identified under the assessment, information on species, specimens, volumes exported as well as the status of export quotas, the country, date of issuance and number of export permits and re-export certificates that are sent to the CITES Secretariat by relevant Parties.

13.45 Pending the results of the assessment referred to in Decision 13.44, and subject to the availability of funds, the interested Parties may submit a proposal for a pilot project on the provision of a database, for consideration by the Standing Committee at its 54 th meeting.

13.46 In accordance with the Standing Committee's decision regarding the proposal referred to in Decision 13.45, the Parties concerned should report on the outcome of this pilot project and its recommendations at the 14th meeting of the Conference of the Parties.

\section{Directed to the Secretariat}

13.47 Subject to the availability of funds and the Standing Committee's support for a proposed pilot project, as referred to in Decision 13.46, all relevant information and documentation shall be forw arded on a regular basis to the relevant Party in charge, as approved by the Standing Committee at its 54 th meeting.

\section{Sea cucumbers}

\section{Directed to the Animals Committee}

13.48 The Animals Committee shall:

a) review the proceedings of the International technical w orkshop on the conservation of sea cucumbers in the families Holothuriidae and Stichopodidae (March 2004, Kuala Lumpur), as well as those of the forum on Advances in Sea Cucumber Aquaculture and Management (ASCAM) convened by the Food and Agriculture Organization of the United Nations (October 2003; Dalian); and

b) prepare, for consideration at the 14th meeting of the Conference of the Parties, a discussion paper on the biological and trade status of sea cucumbers in the above families to provide scientific guidance on the actions needed to secure their conservation status.

\section{Directed to the Secretariat}

13.49 The Secretariat shall assist in obtaining funds to support the preparation of the Animals Committee discussion paper on the biological and trade status of sea cucumbers in the families Holothuriidae and Stichopodidae. 


\section{Trade in plants}

\section{Directed to the Secretariat}

9.38 ${ }^{1}$ Arrangements shall be made for the following activities:

(Rev.

CoP11) a) a review of the levels of trade in Appendix-I cycads in the family Zamiaceae, i.e. the genera Ceratozamia, Encephalartos and Microcycas; and

b) an investigation of the international trade in aloe products including an assessment of the impact on wild populations and methods of improving trade controls.

\section{Medicinal plants}

\section{Directed to the Plants Committee}

13.50 The Plants Committee shall prepare amendments to annotations for medicinal plants included in Appendix II that adequately reflect the current commodities in international trade and their relative impact on the wild populations in range States.

13.51 The amended annotations shall focus on those commodities that first appear in international trade as exports from range States and on those that dominate the trade and the demand for the wild resource.

13.52 The Plants Committee shall draft proposals to amend the Appendices in this respect for the Depositary Government to present for consideration at the 14th meeting of the Conference of the Parties.

\section{Directed to the Secretariat}

13.53 Subject to the availability of external funding, the Secretariat shall prepare a glossary with definitions and training materials that illustrate the content of the amended annotations, the terms used and their practical application during enforcement and controls.

\section{Tree species}

\section{Directed to the Plants Committee}

13.54 The Plants Committee shall, during the period between the 13th and 14th meetings of the Conference of the Parties, consider the opportunity to develop proposals to amend the Appendices on the basis of the Contribution to an Evaluation of Tree Species using the new CITES-listing criteria, and the results of regional workshops on sustainable management of timber species in 2005 and 2006.

1 The original paragraphs a) to c) were deleted following the 12th meeting of the Conference of the Parties. 


\section{Bigleaf mahogany}

\section{Directed to the Plants Committee}

13.55 The Bigleaf Mahogany (Sw ietenia macrophylla) Working Group shall continue its work under the Plants Committee. The Working Group shall primarily comprise the range States of the species, the principal importing countries and at least one member of the Plants Committee.

13.56 The Plants Committee shall present a report at the 14th meeting of the Conference of the Parties on the progress made by the Working Group.

\section{Directed to Parties}

13.57 The countries belonging to the Bigleaf Mahogany Working Group should attempt to ensure the presence of their representatives at the meetings of the Group.

13.58 The range States of Sw ietenia macrophylla should:

a) prepare and officially adopt, as a priority, mahogany management plans at national and subregional level;

b) promote the conduct of forest inventories, as well as progress and promote programmes to determine and monitor the distribution, population size and conservation status of mahogany;

c) develop capacity-building programmes in monitoring and management relating to CITES procedures and documents. To this end, if considered appropriate, it may request assistance from the Plants Committee and the Secretariat;

d) submit reports on progress in the implementation of this Decision to the Secretariat no later than 90 days before the 16th meeting of the Plants Committee, so that the Secretariat may include them in a report that it will present at that meeting; and

e) establish, if considered necessary, working groups to implement the present Decision.

\section{Directed to Parties, the Secretariat and intergovemmental and non-govemmental organizations}

13.59 Parties, the CITES Secretariat and intergovernmental and non-governmental organizations shall seek ways to share information though the organization of regional workshops, capacity-building programmes, the exchange of experiences and the identification of financial resources.

\section{Harpagophytum}

\section{Directed to the Plants Committee}

13.60 The Plants Committee shall decide on what action is required for outstanding reports from the importing countries of Harpagophytum. 


\section{Agarwood-producing taxa}

\section{Directed to Parties}

13.61 The DNA work currently being undertaken by the National Herbarium of the Netherlands under contract to the Secretariat should continue and should be aimed at investigating the options for the development of identification tools based on molecular analysis.

13.62 As the trade is in the readily-identifiable product of agarw ood, studies should include all known agarwood-producing taxa, not only the CITES-listed species Aquilaria malaccensis, and the possible inclusion of all agarwood-producing taxa in Appendix II needs to be discussed.

13.63 Further field research should be conducted on trade dynamics, including in the major importing and re-exporting States and territories of Southeast Asia, East Asia and the Middle East.

\section{Directed to the Secretariat}

13.64 The Secretariat should invite IUCN to re-evaluate the threatened status of all agarw oodproducing taxa according to the IUCN criteria (Version 3.1).

13.65 The Secretariat shall:

a) assist in obtaining funding from interested Parties, intergovernmental and nongovernmental organizations, exporters, importers and other stakeholders to support a capacity-building workshop on trade in agarwood prior to the 14th meeting of the Conference of the Parties;

b) contingent on availability of external funding, cooperate with exporting and importing countries, as well as significant re-exporting countries and relevant experts, to convene a capacity-building workshop aimed at improving enforcement and implementation of the listing of Aquilaria malaccensis and other agarwoodproducing species;

c) in addition to basic enforcement and implementation issues, include in the workshop a discussion of registration and labelling systems, types of agarwood products in trade and the potential for establishing personal effects exemptions for each, and the usefulness of such approaches for effective implementation; and

d) present at the workshop any new information from the Plants Committee on identification of agarwood products in trade, as well as information that would assist in determining sustainable harvest levels and making non-detriment findings.

\section{Management of annual export quotas}

\section{Directed to the Standing Committee}

12.72 The Standing Committee shall consider the issue of improving the management of

13.66 The Standing Committee shall instruct its Export Quota Working Group to develop guidelines for Parties to establish, implement, monitor and report national export quotas for CITES-listed taxa. 


\section{Capacity-building programme for science-based establishment and implementation of voluntary national export quotas for Appendix-II species}

\section{Directed to Parties}

12.90 The Parties should seek funding in order to:

a) assist the Secretariat in implementing its capacity-building programme dealing with the scientific basis for establishment and implementation of voluntary national export quotas for Appendix-II species; and

b) support exporting countries in their efforts to gather information needed to set quotas.

\section{Directed to the Secretariat}

12.91 The Secretariat is encouraged to continue to develop and refine its capacity-building programme dealing with the scientific basis for development, establishment, and implementation of voluntary national export quotas for Appendix-II species, and shall, as appropriate, consult with the Animals Committee and Plants Committee on this programme. This consultation may include:

a) solicitation of input from the Committees regarding materials used in the capacitybuilding programme for voluntary national export quotas for Appendix-II species; and

b) a request for new information from the Committees on methods used for establishing quotas and for relevant case studies on the establishment of quotas.

12.92 To facilitate the development and refinement of its capacity-building programme for voluntary national export quotas for Appendix-II species, the Secretariat may invite Parties to provide new information regarding the scientific basis for establishment and implementation of such quotas, and regarding the most appropriate ways of disseminating relevant information to the Parties in a timely and cost-effective manner.

12.93 The Secretariat shall seek funding to:

a) continue its capacity-building programme for the scientific basis for establishment and implementation of voluntary national export quotas for Appendix-II species; and

b) support exporting countries in their efforts to gather information needed to set quotas.

\section{Review of Significant Trade}

13.67 The Conference of the Parties has adopted the Terms of reference for an evaluation of the Review of Significant Trade contained in Annex 3 to these Decisions. 


\section{Production systems for specimens of CITES-listed species}

\section{Directed to the Animals and Plants Committees}

13.68 The Animals and Plants Committees shall establish an intersessional joint working group with the following Terms of Reference:

a) the working group shall be composed of members and observer Parties within the Animals and Plants Committees, from as many of the six different CITES regions as possible, with expertise in determining and defining the existing production systems for specimens of CITES-listed species of animals and plants;

b) the working group shall:

i) focus on clearly defining key elements of the different production systems for specimens of CITES-listed species of animals and plants, and, if appropriate, developing as far as possible a list of specific production systems currently being utilized by Parties;

ii) determine under which existing CITES permit source code each production system appropriately fits and whether the addition of any new source codes is necessary; and

iii) consider the definition of 'ranching' within the context of existing CITES Resolutions;

c) to avoid duplication of work, the working group should use, as a basis for its discussions, the following documents on production systems from previous meetings of the Animals and Plants Committees:

i) AC20 WG6 Doc. 1 - Report of the AC20 working group on Control of captive breeding, ranching and wild harvest production systems for Appendix-II species;

ii) AC20 Inf. 18 - Plant and animal production systems and CITES source codes (prepared by the United States);

iii) AC20 Inf. 15 - Draft review of production systems - Report to CITES Secretariat (prepared by the IUCN/SSC W ildlife Trade Programme);

iv) PC12 Doc. 23.1 - CITES plant production systems (prepared by the ViceChairman of the Plants Committee);

v) AC19 WG4 Doc. 1 (Rev. 1) - Report of the AC19 working group on Control of captive breeding, ranching and wild harvest production systems for Appendix-II species;

vi) Annex 8.2 of the Summary record of the 18th meeting of the Animals Committee - Report of the Coral Working Group on coral production systems;

vii) AC17 Inf. 12 - Wild fauna management and production systems: Their description, conservation implications and treatment by CITES (prepared by Dr Hank J enkins of Creative Conservation Solutions); and

viii) AC17 Doc. 14 (Rev. 1) - Control of captive breeding, ranching and wild harvest production systems for Appendix-II species (prepared by Dr Hank J enkins of Creative Conservation Solutions);

d) in evaluating production systems and determining under which source code each production system fits, the working group should take into account that both the Animals and Plants Committees have agreed that source codes should not be used to replace non-detriment findings by Scientific Authorities; 
e) the working group should provide interim reports on its progress toward the achievement of its goals at each Animals and Plants Committee meeting between the 13th and 14th meetings of the Conference of the Parties;

f) after incorporating suggestions from both the Animals and Plants Committees, the working group should submit a final report, which may include a draft resolution of the Conference of the Parties, for consideration at the 14th meeting of the Conference of the Parties; and

g) the working group should carry out the majority of its work via email to keep costs to a minimum.

\section{CITES permits and certificates}

\section{Directed to the Secretariat}

12.76 The Secretariat shall study and evaluate the possibility of creating a future centralized system that would allow the establishment of a communications network through the CITES website that would make it possible to check the authenticity and veracity of permits and certificates issued and received by each of the Parties.

\section{Electronic permitting}

\section{Directed to the Standing Committee}

13.69 Based on the information provided by the Secretariat, and subject to the provision of appropriate funding, the Standing Committee shall establish a working group to further explore the use of information technology or electronic systems to enhance the implementation of CITES and report at the 14th meeting of the Conference of the Parties.

\section{Directed to the Secretariat}

13.70 Subject to the provision of appropriate funding, the Secretariat should:

a) advise the Parties on the work done by UNEP-WCMC in the development of simple Internet-based software tools and provide recommendations based on experience and testing by Parties;

b) evaluate the experience of other permit-based agreements or conventions, such as CCAMLR, in using electronic permitting systems;

c) provide guidance to the Parties on the extent to which it may be practicable to make use of computerized systems to meet their obligations under CITES and on the extent to which this would be consistent with the obligations set out in the Convention and related Resolutions and Decisions of the Parties and subject to the direction of the Standing Committee; and

d) engage the World Customs Organization on data harmonization and how it relates to the implementation of CITES and report on their efforts at the 54th meeting of the Standing Committee. 


\section{Personal and household effects}

\section{Directed to the Standing Committee}

13.71 The Standing Committee, in consultation with the Secretariat, Parties and relevant organizations, shall develop a process for consideration of specimens of personal and household effects of Appendix-II species which may need to have quantitative limits set to be exempted from permitting requirements according to Article VII, paragraph 3 , of the Convention at the 14th meeting of the Conference of the Parties.

\section{Non-commercial loan, donation or exchange of museum and herbarium specimens}

\section{Directed to the Secretariat}

12.79 The Secretariat shall develop a brochure that will illustrate the importance of registering scientific institutions under Article VII, paragraph 6 , of the Convention and demonstrate how the registration procedures can be applied in a simplified manner.

\section{Artificially propagated plants}

\section{Directed to the Plants Committee}

13.72 The Plants Committee shall monitor the effects of implementing the revised definition of 'artificially propagated' contained in Resolution Conf. 11.11 (Rev. CoP13), pertaining to the production of specimens of A ppendix-I species grow $\mathrm{n}$ from wild-collected seeds and spores, and report their findings at the 14th meeting of the Conference of the Parties. This report shall particularly note any adverse effects on the conservation of Appendix-I species that have been subject to this revised definition.

\section{Directed to the Secretariat}

13.73 The Secretariat shall consider the revised definition of 'artificially propagated' contained in Resolution Conf. 11.11 (Rev. CoP13) and make only the necessary changes in Resolution Conf. 9.19 to remove any inconsistency between the two Resolutions that may have been caused by revising the definition of 'artificially propagated'.

\section{National wildlife trade policy reviews}

\section{Directed to the Secretariat}

13.74 Contingent on the availability of external funding, the Secretariat shall, in collaboration with interested Parties and building on the findings and recommendations of the workshop on trade policy and economic incentives (Geneva, 2003):

a) conduct, in cooperation with the Parties, a review of their national policies regarding the use of and trade in specimens of CITES-listed species, taking into account economic incentives, production systems, consumption patterns, market access strategies, price structures, certification schemes, CITES-relevant taxation and subsidy schemes, property rights, mechanisms for benefit sharing and 
reinvestment in conservation, as well as stricter domestic measures that Parties apply or are affected by;

b) compile and synthesize the information provided by the Parties, and produce a report analysing the impacts of national policies for trade in CITES-listed species in terms of socio-economic and conservation benefits and costs, including on the economic value of the species, levels of legal and illegal trade, improvement of the livelihood of local communities, and on how they affect the role of the private sector involved in such trade;

c) report at the 54th and subsequent meetings of the Standing Committee and at the 14th meeting of the Conference of the Parties on the progress made with regard to the implementation of this Decision; and

d) submit a project proposal to the Global Environment Facility, and other funding institutions and development agencies, to seek financial support to prepare the trade policy reviews in the interested countries, in the context of their national and regional strategies for biodiversity conservation.

13.75 The Secretariat shall invite all Parties, governmental, intergovernmental and nongovernmental organizations to provide technical assistance for conducting the national wildlife trade policy reviews.

\section{Further work on economic incentives}

\section{Directed to the Secretariat}

13.76 The Secretariat shall invite all Parties and relevant organizations to provide information, experiences and, where possible, outcomes on their use of economic incentives and report at the 53rd meeting of the Standing Committee for consideration on the manner in which this might be taken up for further action on capacity building and possible regional cooperation.

13.77 Subject to the availability of funding, the Secretariat shall continue its cooperation on incentive measures with the CBD Secretariat and other biodiversity-related conventions (e.g. Ramsar and CMS), as well as with the private sector and relevant governmental, intergovernmental and non-governmental organizations. This cooperation shall focus, inter alia, on the exchange of experiences in the design and use of economic incentives for sustainable management of wild fauna and flora, compilation of case-studies, best practices and lessons learnt, as well as the development of targeted recommendations, operational guidelines and associated instruments for the sustainable use of wild flora and fauna.

\section{Relationship between ex situ production and in situ conservation}

\section{Directed to the Standing Committee}

13.78 The Standing Committee shall, through its clearing-house mechanism, decide on the appropriate way to continue consideration of the relationship between ex situ production (of animals and plants) and in situ conservation in the context of CITES. It shall establish precise terms of reference for the CITES bodies that should be involved in this work, set timelines for the work to be done, and report on progress at the 14th meeting of the Conference of the Parties. 


\section{National laws for implementation of the Convention}

\section{Directed to Parties}

13.79 a) All Parties and dependent territories with legislation not yet categorized should provide to the Secretariat, before the 53rd meeting of the Standing Committee and in one of the three working languages of the Convention, copies of all existing legislation that implements the provisions of the Convention.

b) Any new Party that adheres to the Convention before the 14th meeting of the Conference of the Parties should provide to the Secretariat, within three months after the Convention enters into force for that Party and in one of the three working languages of the Convention, copies of all existing legislation which implements the provisions of the Convention.

c) All Parties and dependent territories whose legislation has been placed in Category 2 or 3 should indicate their progress in enacting adequate legislation for implementation of the Convention by submitting to the Secretariat before the 53rd meeting of the Standing Committee and its subsequent meetings:

i) an initial or revised CITES Legislation Plan indicating the procedures, actions and time-frames needed to enact legislation;

ii) draft legislation and a translation of this draft legislation into one of the three working languages of the Convention; or

iii) enacted legislation and a translation of this legislation into one of the three working languages of the Convention.

13.80 In accordance with the action plans agreed with the Secretariat, Nigeria and Paraguay should enact adequate legislation for implementation of the Convention by the 53rd meeting of the Standing Committee.

13.81 The following Parties and dependent territories should enact adequate legislation for implementation of the Convention by 30 September 2006: Albania; Aruba (NL); Azerbaijan; Bailiwick of Guernsey (GB); Bailiwick of J ersey (GB); Bermuda (GB); Bhutan; British Indian Ocean Territory (GB); British Virgin Islands (GB); Cayman Islands (GB); Croatia; Falkland Islands (Islas Malvinas)'; French Polynesia (FR); Greenland (DK); Iceland; Ireland; Kuwait; the Libyan Arab Jamahiriya; Lithuania; Macao Special Administrative Region (CN); Mayotte (FR); Montserrat (GB); Netherlands Antilles (NL); New Caledonia (FR); Qatar; Republic of Moldova; Sao Tome and Principe; Serbia and Montenegro; Slovenia; the Syrian Arab Republic; the former Yugoslav Republic of Macedonia; and Wallis and Futuna Islands (FR).

\section{Directed to the Standing Committee}

13.82 With respect to Parties and dependent territories that do not comply with Decisions $13.79,13.80$ or 13.81 , or decisions of the Standing Committee in relation to national laws for implementation of the Convention, the Standing Committee shall consider appropriate measures, which may include recommendations to suspend commercial trade in specimens of CITES-listed species to and from such Parties.

A dispute exists between the Governments of Argentina and the United Kingdom of Great Britain and Northern Ireland concerning sovereignty over the Falkland Islands (Malvinas). 


\section{Directed to the Secretariat}

\subsection{The Secretariat shall:}

a) with regard to Parties with legislation in Category 2 or 3 or not yet categorized, compile and analyse the information submitted by Parties on legislation adopted before the 14th meeting of the Conference of the Parties to fulfil the requirements laid down in the text of the Convention and Resolution Conf. 8.4;

b) prepare or revise the analyses of national legislation and the categories, and advise the Parties concerned of the initial or revised analyses, specifying any requirements that are not yet met;

c) provide technical assistance to Parties requesting advice in the formulation of legislative proposals for CITES implementation by providing, to the extent resources are available:

i) legal guidance in the preparation of necessary legislative measures;

ii) training of CITES authorities and other relevant bodies responsible for the formulation of wildlife trade policies or legislation; and

iii) any specific support relevant to the fulfilment of the legislative requirements for the implementation of CITES;

d) report at the 53rd and subsequent meetings of the Standing Committee on Parties' progress in enacting adequate legislation and, if necessary, recommend the adoption of appropriate compliance measures, including suspension of trade pursuant to decisions taken by the Standing Committee;

e) identify for the Standing Committee any countries that require attention as a priority under the National Legislation Project; and

f) report at the 14th meeting of the Conference of the Parties on:

i) the legislation adopted by the Parties to implement the Convention and any recommendations relating to Parties that have not adopted adequate legislation for implementation of the Convention; and

ii) any progress concerning technical assistance provided to the Parties in the development of their national legislation for implementation of CITES.

\section{Enforcement matters}

\section{Directed to Parties}

13.84 Parties should submit to the Secretariat, by 31 May 2005, contact details of each of their relevant national law enforcement agencies responsible for investigating and prosecuting illegal trafficking in wild fauna and flora. The Secretariat shall distribute, via a Notification to the Parties, a form to facilitate the submission of this information.

\section{Directed to the Standing Committee}

13.85 The Standing Committee, at its 54th meeting, shall consider a report from the Secretariat on compliance by the Parties with Decision 13.84.

\section{Directed to the Secretariat}

13.86 The Secretariat shall distribute, via a Notification to the Parties, the guidance on submission of enforcement-related information prepared by the CITES Enforcement Expert Group. 
13.87 The Secretariat shall increase its efforts on capacity building and training of CITES enforcement officers, in particular in developing countries, countries with economies in transition and small island developing States, and assist in providing expertise also using regional organizations such as the one existing under the Lusaka Agreement.

\section{Violations of the Convention by diplomats and troops serving under the flag of the United Nations}

\section{Directed to Parties}

9.15 The Parties are urged to remind their diplomatic missions, their delegates on mission in foreign countries and their troops serving under the flag of the United Nations that they are not exempted from the provisions of the Convention.

\section{Transport of live specimens}

\section{Directed to the Animals Committee}

13.88 The Animals Committee, in collaboration with interested non-governmental organizations and the Secretariat, shall:

a) develop recommendations regarding transport of live animals by road, rail or ship, and regarding cost-effective options for containers and packing materials for all means of transport to supplement, where necessary, the IATA Live Animals Regulations;

b) assist in identifying model practices concerning the transport and preparation for shipment of live wild animals, and develop recommendations to the Parties regarding the proper preparation, proper handling and transportation of live animals, particularly in exporting countries; and

c) report at the 14th meeting of the Conference of the Parties on the implementation of this Decision.

13.89 The A nimals Committee, in consultation with the Plants Committee and the Secretariat, shall:

a) undertake a review of Resolution Conf. 10.21 on Transport of live animals, in order to inter alia:

i) revise the requirements regarding the collection, submission and analysis of data on mortality and injury or damage to health in transport of live animals, domestic measures directed to Parties, and reporting obligations;

ii) incorporate references to the transport of live plants; and

iii) clarify how IATA manuals and regulations can be mechanisms through which up-to-date guidance on the transport of live animals and plants of CITES-listed species can be provided, replacing the CITES Guidelines for transport and preparation for shipment of live wild animals and plants; and

b) report at the 14th meeting of the Conference of the Parties on the implementation of this Decision. 


\section{Reporting requirements}

\section{Directed to the Secretariat}

13.90 The Secretariat shall identify ways to reduce the reporting burden on Parties, in the context of its ongoing efforts to consolidate the Resolutions and Decisions of the Conference of the Parties, its collaboration with UNEP-WCMC and interested Parties on the development of simple software systems and Internet-based modules and its involvement in cooperative implementation of the Environmental Management Group recommendations on the harmonization of information management and reporting, and report at the 14th meeting of the Conference of the Parties on the results of this work.

13.91 The Secretariat shall incorporate into the Guidelines for the preparation and submission of CITES annual reports the specific guidance on plants, raw ivory, corals and timber contained in Resolution Conf. 11.17 (Rev. CoP13).

13.92 The Secretariat shall continue to collaborate with the secretariats of other biodiversityrelated conventions in order to ensure the harmonization of information management and reporting.

\section{Review of the Appendices}

\section{Directed to the Animals Committee}

13.93 The Animals Committee shall, immediately following the 13th meeting of the Conference of the Parties, include the Felidae in its Review of the Appendices. This review shall initially focus on the listing of the Lynx species complex, which includes species that are listed because of similarity of appearance, such as Lynx rufus. In addition to evaluating the listings of these species against the criteria for inclusion of species in Appendices I and II contained in Resolution Conf. 9.24 (Rev. CoP13), the Animals Committee shall assess the management and enforcement measures available to achieve effective control of trade in these species so as to resolve the continued need for look-alike listings. This assessment should also include a review of trade information to determine whether these species are actually confused in trade or whether the look-alike problem is merely hypothetical. The Animals Committee shall provide a report at the 14th meeting of the Conference of the Parties on the progress of the review of all Felidae and particularly on their review of Lynx spp. and look-alike issues.

\section{Standard nomenclature for birds}

\section{Directed to the Nomenclature Committee}

13.94 The Nomenclature Committee shall conduct a review of the status of the standard nomenclatural references adopted for the species of the Class Aves listed in the Appendices, inform the Conference of the Parties on the matter at its 14th meeting and, if necessary, recommend changes to update them. 


\section{Fossil corals}

\section{Directed to Parties}

13.95 The Parties that are involved in the trade in stony corals should, by the end of 2005, determine how they will interpret the annotation exempting fossil corals from the provisions of the Convention and provide this interpretation to the Secretariat for distribution to the Parties.

\section{Directed to the Animals Committee}

13.96 The Animals Committee shall proceed with an analysis of the Parties' interpretation of the annotation on fossil corals and other tasks necessary to undertake a review of Resolution Conf. 11.10 (Rev. CoP12) and report to the Secretariat by the end of 2006.

\section{Directed to the Secretariat}

13.97 The Secretariat shall communicate the report of the Animals Committee regarding the interpretation of the annotation exempting fossil corals to the Parties via a notification before the 14th meeting of the Conference of the Parties.

\section{Annotation for Orchidaceae included in Appendix II}

\section{Directed to Parties}

13.98 All Parties should monitor the implementation of the annotation to Orchidaceae spp. included in Appendix II and report to the Plants Committee.

\section{Directed to the Plants Committee}

13.99 The Plants Committee should report at the 14th meeting of the Conference of the Parties on the implementation of the annotation to Orchidaceae spp. included in Appendix II.

\section{Implementation of the Quito Declaration}

\section{Directed to the Secretariat}

\subsection{The Secretariat shall:}

a) identify a coordinating mechanism to work jointly with UNEP/ROLAC and other multilateral environmental agreements to implement the Quito Declaration (Annex 4 to these Decisions); and

b) identify financial resources for the purpose of implementing the actions that derive from the Quito Declaration, especially those referring to:

i) organization of regional meetings, at least one regional meeting before each meeting of the Conference of the Parties; and

ii) support for the different activities to be carried out by the regional representatives regarding CITES implementation. 


\section{Capacity building in the Oceanian region}

\section{Directed to the Secretariat}

\subsection{The Secretariat shall:}

a) seek funding to convene a capacity-building workshop and regional meeting for the Oceanian region before the 54th meeting of the Standing Committee, in order to improve regional implementation of the Convention; and

b) subject to availability of funds, invite the Parties of the Oceanian region, Party observers, non-party States and regional intergovernmental organizations as may be appropriate.

\section{Bushmeat}

\section{Directed to Parties, intergovernmental organizations, international aid agencies, non-governmental organizations and other donors}

13.101 Governments and intergovernmental organizations, international aid agencies, nongovernmental organizations and other donors are encouraged to support the work of the Central Africa Bushmeat Working Group and its member States to implement national action/management plans and to develop a database regarding trade in bushmeat.

\section{Directed to the Central Africa Bushmeat Working Group}

13.102 The CITES Bushmeat Working Group, renamed the Central Africa Bushmeat Working Group, is encouraged to continue its work and report through the CITES Secretariat at the 14th meeting of the Conference of the Parties on progress made in implementing national action plans relating to the trade in bushmeat and other initiatives it takes regarding this subject.

\section{Directed to the Secretariat}

\subsection{The Secretariat should:}

a) write to the Secretariat of the Convention on Biological Diversity (CBD) to draw its attention to the growing concern over the unsustainable trade in bushmeat species and to urge the Parties to CBD to make recommendations that will help to address this issue by developing policies to protect native habitats and promote sustainable utilization of forest resources;

b) invite the Food and Agriculture Organization of the United Nations (FAO) to consider whether it would be prepared to convene an international workshop to facilitate the development of an action plan to develop a coordinated approach to tackling the issues of poverty, habitat degradation, human population growth and utilization of natural resources associated with the unsustainable trade in bushmeat;

c) invite FAO to write to the Secretaries-General of treaties and international organizations such as the Convention on Biological Diversity, the Convention on the Conservation of Migratory Species of Wild Animals, the International Tropical Timber Organization, the United Nations Conference on Trade and Development, the United Nations Development Programme, the United Nations Environment Programme, including its Great Apes Survival Project, and the United Nations Population Fund to participate in this workshop and encourage States that participate in these treaties and organizations to become involved in this workshop; and 
d) subject to the agreement of FAO, invite all CITES Parties and other interested bodies to provide the necessary funding to support this workshop.

\section{Master's course on Management, Access and Conservation of Species in Trade}

\section{Directed to Parties}

13.104 Parties are called upon to provide financial assistance to the University of Cordoba (Spain) and to the International University of Andalusia (Spain) in order to support the continuation of the Master's course on Management, Access, Conservation and Trade of Species: The International Framew ork.

\section{Directed to the Standing Committee and the Secretariat}

13.105 The Standing Committee and the Secretariat shall seek external funding to support the participation in the Master's course of students from developing countries and countries with economies in transition. 


\section{STRATEGIC VISION}

\section{Purpose \\ TO ENSURE THAT NO SPECIES OF WILD FAUNA OR FLORA BECOMES OR REMAINS SUBJ ECT TO UNSUSTAINABLE EXPLOITATION BECAUSE OF INTERNATIONAL TRADE}

The purpose of the Strategic Plan is to improve the working of the Convention so that international trade in wild fauna and flora is increasingly and consistently conducted at sustainable levels. Where uncertainty remains as to whether trade is sustainable, the precautionary principle will prevail as the ultimate safeguard. How ever, a successful outcome of the implementation of the Strategic Plan will be a reduction in the need to bring the precautionary principle into play. The Strategic Plan confirms the recognition by the Parties that sustainable trade in wild fauna and flora can make a major contribution to securing the broader and not incompatible objectives of sustainable development and biodiversity conservation. It also recognizes that the Convention must continue to ensure that proper trade mechanisms are put in place. These depend upon the availability of and access to reliable scientific data and to information generated by effective monitoring systems to counter over-exploitation. But information by itself is not enough and such trade mechanisms also require strong national capacity backed by good cooperation at national, regional and global levels. In order to achieve this purpose, seven goals have been identified as the key components of the Strategic Plan. It is important to realize that the successful achievement of Goal 7, allied to Goal 5, will greatly enhance the achievement of Goals 1, 2, 3 and 4. Securing a strong financial basis must therefore be given a major effort, without overlooking the importance of the other goals.

\section{Introduction}

The Convention on International Trade in Endangered Species of Wild Fauna and Flora (CITES) was signed on 3 March 1973. The Convention resulted from an expression of concern by the 1972 United Nations Conference on the Human Environment in Stockholm, Sw eden, concerning the rate at which the world's wild fauna and flora were being threatened by unregulated international trade. Drafts of what became the Washington Convention or CITES were sent to Governments by the World Conservation Union (IUCN) in 1967, 1969 and 1971. The final draft, after review by Governments, the General Agreement on Tariffs and Trade (GATT), the Food and Agriculture Organization (FAO) and others, was discussed at a Plenipotentiary Conference in Washington, DC, United States of America. At its conclusion, 21 of the 80 countries represented at the Conference signed the Convention. The Convention entered into force, after ratification by 10 countries, on $1 \mathrm{~J}$ uly 1975 .

In the intervening 25 years, the number of countries that have acceded to the Convention has continued to increase. With more than 150 Parties, CITES is widely regarded as one of the most important legal international conservation instruments. During this period, the Conference of the Parties has show $n$ itself to be capable of adapting to changing circumstances and, through the adoption of Resolutions, has demonstrated an ability to construct practical solutions to increasingly complex wildlife trade problems. For example, the Parties have adopted 'ranching' and other control techniques such as annual quotas for managing the harvesting of some Appendix-I-listed species at levels that do not threaten their conservation status. In 1994 the Conference of the Parties identified the information requirements necessary to extend the ranching concept for specific application to marine turtles.

More recently, proposals to amend the Appendices to the Convention have become increasingly complex and sensitive. As a result, at its eighth meeting (Kyoto, 1992), the Conference of the Parties initiated a process to review the 'Bern Criteria' that had been in place since 1976 and were proving to be too general and inadequate. This resulted in the adoption of new and more objective criteria that are scientifically based to guide amendments to Appendices I and II. In adopting the new criteria, the Parties recognized the increasing acceptance by the international community to apply the precautionary principle to the decision-making process. Accordingly, its application is embraced in considerations involving the transfer of species from Appendix I to 
Appendix II. When the new criteria were adopted in 1994, the Parties, as an expression of the need for a flexible approach to CITES implementation, agreed to incorporate a review process into the new criteria. This process has commenced and will strengthen the scientific basis of the decision-making process for amending the Appendices to the Convention.

At its ninth meeting (Fort Lauderdale, 1994), the Conference of the Parties commissioned a review of the Convention's effectiveness. The principal purposes of the review were to evaluate the extent to which the Convention had achieved its objectives and the progress made since CITES came into being and, most importantly, to identify deficiencies and requirements necessary to strengthen the Convention and help plan for the future. At its 10th meeting (Harare, 1997), the Conference agreed to an Action Plan for implementing certain findings and recommendations of the review. A central finding was the need for a strategic plan.

With this Strategic Plan, the Conference of the Parties to the Convention has mapped the Convention's direction as it enters the new millennium. The plan forms the basis for the Convention's participation in the wider international nature conservation arena as developed since the 1992 Earth Summit in Rio de J aneiro and includes issues such as:

- stew ardship of natural resources and their use at sustainable levels;

- $\quad$ safeguarding of wildlife as integral to the global ecosystem on which all life depends;

- need for deeper understanding of the cultural and economic issues at play in producer and consumer countries; and

- wider involvement of civic society in the development of conservation policies and practices.

\section{Strategic Plan}

This Plan presents the Convention's Strategic vision as it enters the new millennium. It clearly focuses on a limited number of priority goals and objectives deemed critical to meeting the Convention's purpose to ensure that no species of wild fauna or flora becomes or remains subject to unsustainable exploitation because of international trade. If actively pursued, this Plan will bring the Convention's purpose closer to reality by the year 2005 .

\section{GOAL 1: ENHANCE THE ABILITY OF EACH PARTY TO IMPLEMENT THE CONVENTION}

The effectiveness of the Convention depends on a coordinated process of implementation that guarantees, in the long term, the achievement by all Parties of the Convention's purpose and objectives outlined in this Strategic Plan. The need for a coordinated process has grow $n$ as the Convention faces up to trade issues involving species that often fall beyond the direct reach of the Management and Scientific Authorities. It is also recognized that for trade to be carried out in a responsible manner and based on sustainable use, social and economic incentives are needed to bring local communities and local authorities into partnership with government under an appropriate legislative, policy and financial framew ork.

Enhanced ability at the national level therefore means improving the following:

- organizational capacity and cooperation;

- policy formulation;

- community, local authority and government partnerships;

- $\quad$ direct benefit and revenue derivation;

- availability of information on which decisions are based;

- national legislation and law enforcement capability; and

- better accessibility and understanding of the Convention's requirements.

These improvements, in turn, should enable a better management of wild animals and plants, and thus reduce the need to include species in the CITES Appendices. It is also important to consider the potential of regional coordination and collaboration for national capacity-building 
efforts. Finally, strong national and regional participation in the deliberations and implementation of the Convention can only be fully effective if the three working languages are given proper respect and equity.

\section{Objective 1.1}

To assist in the development of appropriate domestic legislation and policies that encourage the adoption and implementation of social and economic incentives allied to legal instruments that:

- $\quad$ promote and regulate sustainable management of wild fauna and flora;

- $\quad$ promote and regulate responsible trade in wild fauna and flora; and

- promote the effective enforcement of the Convention.

\section{Objective 1.2}

To strengthen the administrative, management and scientific capacity of Parties by improving the coordination between Management and Scientific Authorities and other national agencies responsible for wild animals and plants.

\section{Objective 1.3}

To strengthen the enforcement capacity of the Parties and to improve coordination among Management Authorities and other agencies (e.g. police, Customs and veterinary and phytosanitary services).

\section{Objective 1.4}

To facilitate development and use of appropriate technologies and information management systems that enhance and expedite the collection, submission and exchange of accurate information.

\section{Objective 1.5}

To encourage organizations capable of supporting the Convention to assist the Secretariat and Parties in building national information management capacities through training and other activities, and to facilitate improved access to and management of databases.

\section{Objective 1.6}

To ensure that all Parties have at least one designated Scientific Authority with experts in wild fauna and flora.

\section{Objective 1.7}

To improve the coordination between CITES Management and Scientific Authorities, and increase the effectiveness of the latter.

\section{Objective 1.8}

To encourage Parties to develop and implement effective management programmes for the conservation and recovery of species, so that the species will no longer satisfy the criteria for inclusion in the Appendices.

\section{Objective 1.9}

To encourage the proper funding of CITES implementation and enforcement by Parties, and the adoption of national mechanisms that have resource users make a greater contribution to such funding.

\section{Objective 1.10}

To use fully the potential of regional coordination and collaboration in capacity-building efforts. 


\section{Objective 1.11}

To review and simplify, where possible, existing measures, procedures, mechanisms, and recommendations for the implementation of the Convention.

\section{Objective 1.12}

To ensure equity of the three working languages.

\section{GOAL 2: STRENGTHEN THE SCIENTIFIC BASIS OF THE DECISION-MAKING PROCESSES}

The work associated with effective implementation of the Convention entails not only the efficient conduct of business at meetings of the Conference of the Parties and its Committees, but also, and perhaps more importantly, the day-to-day implementation activities of Parties. While other factors may come into play in these arenas, they do not override the need for sound, scientifically-based decisions in all areas of the Convention's application and at all levels of its implementation. Increasingly, the Conference of the Parties is required to address and resolve difficult, complex scientific, trade and management issues involving species that are economically important resources. It is vital to ensure that the Convention's Appendices correctly reflect the conservation and management needs of species, and that decisions regarding these Appendices are grounded in sound scientific information. This view was reaffirmed at the ninth meeting of the Conference of the Parties (Fort Lauderdale, 1994) with the adoption of new criteria for amending Appendices I and II. In this regard, sound scientific activities and practical follow-up action to enhance the conservation and recovery of taxa included in the Appendices are vital elements if the Convention is to be implemented effectively. Within the context of the requirement for non-detriment findings, the Convention is grounded in sound biological principles.

Continued strengthening of the treaty's scientific basis is critical to the continued success of the Convention and its relevance as a major international instrument to ensure that wild animals and plants subject to international trade are used at levels that are sustainable by the wild populations. Vital to this goal is an enhancement of the ability of Scientific Authorities to make the necessary scientific findings and fulfil their other scientific obligations under the Convention.

\section{Objective 2.1}

To ensure that the Convention's Appendices correctly reflect the conservation and management needs of species.

\section{Objective 2.2}

To ensure that decisions to amend the Convention's Appendices are founded on sound and relevant scientific information and meet agreed biological and trade criteria for such amendments.

\section{Objective 2.3}

To improve the scientific basis on which Scientific Authorities make non-detriment findings.

\section{Objective 2.4}

To develop innovative technologies and encourage relevant research, including research into CITES implementation and enforcement, and to pursue these objectives, where appropriate, at the regional level.

\section{GOAL 3: CONTRIBUTE TO THE REDUCTION AND ULTIMATE ELIMINATION OF ILLEGAL TRADE IN WILD FAUNA AND FLORA}

The illegal trade in wild animals and plants is a major factor in the depletion of the world's natural resources in exchange for commercial gain. It undermines the conservation efforts of developing countries, affects the income of rural populations and has driven several species to the brink of extinction.

All countries, whether they are consumers or producers of wild animals and plants, share responsibility to reduce and eventually eliminate illegal trade in wildlife. Successful achievement 
of this responsibility entails coordination and cooperation at all levels - local, national, regional and global. Experience has shown that CITES enforcement would greatly benefit from a higher degree of coordination among the authorities and enforcement agencies within party States. Heightened local awareness of and involvement in wildlife protection activities can further national efforts in combating illegal trade. Also, heightened aw areness of and understanding by the judiciary of their potential role in deterring illegal activities relating to wild fauna and flora w ould further strengthen a Party's effort to stem illegal trade. Enforcement of the Convention is primarily a matter of national competence, but bilateral, regional and global cooperation is elementary in combating illegal international trade effectively. As for a number of other CITES goals, the need for regional cooperation to combat wildlife crime is clearly essential. CITES implementation and enforcement depends to a large degree on efficient border and trade controls. Consequently, the involvement of WCO and ICPO-Interpol in enforcement questions is critical.

\section{Objective 3.1}

To promote a high degree of cooperation, coordination and collaboration between national and international law enforcement agencies.

\section{Objective 3.2}

To stimulate and participate in bilateral, regional and global efforts to combat illegal trade in wild fauna and flora.

\section{Objective 3.3}

To encourage mutual technical assistance, including the exchange of information, in enforcement matters.

\section{Objective 3.4}

To develop appropriate management strategies and incentives for promoting a change from illegal to legal use of wild fauna and flora.

\section{Objective 3.5}

To promote awareness of CITES issues and a greater understanding by the judiciary of the social and economic significance of conservation threats posed by illegal trade in wild fauna and flora.

\section{GOAL 4: PROMOTE GREATER UNDERSTANDING OF THE CONVENTION}

To ensure better implementation of CITES, public support and participation must be enhanced through continuous educational processes that not only raise the profile of the Convention but also recognize its beneficial contribution to conservation through sustainable trade management. Involvement of local communities, NGOs, relevant trade associations, the scientific community, media and the general public is essential to heighten an understanding of the Convention. Efforts are necessary at the regional, national and international levels to provide and disseminate accurate information about the aims and functioning of the Convention in order to heighten aw areness and improve its implementation. Special attention also needs to be given to public understanding of issues relating to plants.

\section{Objective 4.1}

To strengthen communication and collaboration with national and international NGOs.

\section{Objective 4.2}

To strengthen alliances with relevant local communities, consumer groups and traders.

\section{Objective 4.3}

To promote greater aw areness among and cooperation with the scientific community. 


\section{Objective 4.4}

To produce and disseminate informative materials to a broad public at a local, national and regional levels.

\section{Objective 4.5}

To improve communication and collaboration with the media.

\section{Objective 4.6}

To strengthen knowledge, promote awareness and facilitate enforcement of flora issues in CITES.

\section{GOAL 5: INCREASE COOPERATION AND CONCLUDE STRATEGIC ALLIANCES WITH INTERNATIONAL STAKEHOLDERS}

The Convention states that the Executive Director of the United Nations Environment Programme (UNEP) shall provide a Secretariat. Therefore, the maintenance of an optimal working relationship with UNEP is critical to the proper administration of the Convention. Additionally, the Governing Council of UNEP, at its 20th session (Nairobi, 1999), noted the importance of promoting interlinkages among multilateral environmental conventions and international processes in an effort to achieve a better focus on international policy-making. It calls upon Parties to give due consideration to ways and means to strengthen coherent interlinkages among relevant conventions. Numerous linkages also exist between the aims of CITES and those of other multilateral environmental agreements. Specifically, the missions of CBD and CITES are closely related, thus necessitating a high degree of cooperation and synergy. Cooperation and coordination with species management conventions and agreements are equally important. A number of international organizations such as IUCN and UNEP-WCMC have a wealth of scientific and technical information at their disposal and continue to increase this knowledge through research programmes as well as the updating and maintenance of extensive databases. Again, close cooperation with these organizations is essential for an efficient distribution of responsibilities.

Finally, as CITES achieves its conservation objectives mainly through trade measures, it is important to ensure the continuing recognition and acceptance of CITES measures by WTO and to ensure the mutual supportiveness of the decision-making processes between these bodies.

\section{Objective 5.1}

To ensure an optimal working relationship with UNEP, as well as close coordination and synergy with CBD and other relevant multilateral environmental agreements.

\section{Objective 5.2}

To ensure close cooperation and coordination with related conventions, agreements and associations.

\section{Objective 5.3}

To ensure greater coordination of scientific and technical programmes and, where appropriate, more efficient distribution of responsibilities with relevant technical partners such as IUCN, UNEP-WCMC, TRAFFIC and others.

\section{Objective 5.4}

To ensure continuing recognition and acceptance of CITES measures by WTO and to ensure the 'mutual supportiveness' of the decision-making processes between these bodies.

\section{GOAL 6: PROGRESS TOWARD GLOBAL MEMBERSHIP}

In order for the Convention to achieve its mission, as many countries as possible that are engaged in trade in wild animals and plants should become Parties. Although membership has grown steadily to more than 150 Parties, there are still countries that have not yet become party to CITES. 
The 1983 Gaborone amendment to Article XXI of the Convention envisions accession to the Convention of regional economic integration organizations to which Parties have transferred competence in areas of CITES implementation. To bring such organizations within the Convention, acceptance of the amendment should progress.

\section{Objective 6.1}

To secure at least 20 more Parties to the Convention by 2005 with a special focus on range countries of species subject to significant trade and important consumer countries of wild plants and animals, as well as countries located in regions with relatively low representation.

\section{Objective 6.2}

To encourage acceptance of the 1983 Amendment to Article XXI of the Convention and the subsequent accession by eligible regional economic integration organizations.

\section{GOAL 7: PROVIDE THE CONVENTION WITH AN IMPROVED AND SECURE FINANCIAL AND ADMINISTRATIVE BASIS}

Successful implementation and enforcement of the Convention requires an appropriate level of funding as well as efficient fiscal management and a strong and professional Convention Secretariat. In addition to the need for adequate support at the national level, there is continuing financial need to meet the requirements of operational effectiveness of the Convention and to provide a platform for international coordination and cooperation. Present funding barely covers the Convention's primary expenditures. Programme expenditure on capacity building, scientific research and other projects in support of the aims of the Convention largely depend on voluntary contributions by donors. This financial support is welcome but, if CITES is to continue to play a major role in species conservation, a more stable flow of financial resources is required.

\section{Objective 7.1}

To resolve the problem of late and inadequate contributions to the CITES Trust Fund.

\section{Objective 7.2}

To ensure that the decisions of the Conference of the Parties take full account of financial implications for the CITES Trust Fund.

\section{Objective 7.3}

To secure additional funding for actions under the Convention.

\section{Objective 7.4}

To encourage additional voluntary contributions and to seek new ways of securing financial assistance from the donor community.

\section{Objective 7.5}

To increase the level of realistic planning and forecasting, and to improve financial and implementation reporting.

\section{Delivering the Strategic Plan through the Action Plan}

This Strategic Plan presents a cogent overview of the specific aims of the Convention through 2005. It outlines seven specific goals to meet the Convention's mission, and identifies specific objectives to be achieved to meet those goals. This broad framew ork is designed to provide a unified focus to the Parties in their implementation of the Convention, and as guidance to the Conference of the Parties, its committees and the Secretariat.

The Strategic Plan also serves as an effective outreach and educational tool to provide a context for the Convention to others. It should be recognized that in order for the strategic planning to contribute successfully to the achievement of the Convention objectives, that process must be able to respond to an ever-changing world. The Strategic Plan is not a static document. 
Therefore, the Parties must continue to evaluate progress toward these goals and modify the Strategic Plan over time.

Measurable performance indicators should be established for each of the seven major goals to help identify progress tow ard their successful implementation.

While the Strategic Plan presents an effective framework to focus the Convention through 2005, delivery of that framew ork requires detailed actions by the Parties, the Secretariat and the three Permanent Committees at meetings of the Conference of the Parties. In order to focus these actions and coordinate their implementation, an Action Plan has been prepared. The Action Plan consists of a matrix of action items by responsible entities to indicate what must be done and by whom to help achieve each objective.

As action points are successfully completed, progress toward achievement of the objective must be evaluated and the Action Plan modified accordingly, with the addition or deletion of action points as required.

Procedures should be developed for periodic review and evaluation of ongoing progress tow ard completion and revision of the Action Plan, for review of the status of the goal performance indicators, and to evaluate the subsequent achievement of the goals of the Strategic Plan. Betw een meetings of the Conference of the Parties, this responsibility should be assigned to the Standing Committee.

\section{Acronyms and abbreviations}

CITES Convention on International Trade in Endangered Species of Wild Fauna and Flora

FAO Food and Agriculture Organization of the United Nations

GATT General Agreement on Tariffs and Trade

IATA International A ir Transport Association

ICPO-Interpol International Criminal Police Organization

IUCN The World Conservation Union

MEA Multilateral Environmental Agreement

UNEP United Nations Environment Programme

UNEP-WCMC UNEP World Conservation Monitoring Centre

WCO World Customs Organization

WTO World Trade Organization 


\section{ACTION PLAN}

The goals and objectives laid dow $\mathrm{n}$ in the Strategic Plan determine the pathway that must be followed. To move along that pathway requires actions and these have been set out in this Action Plan.

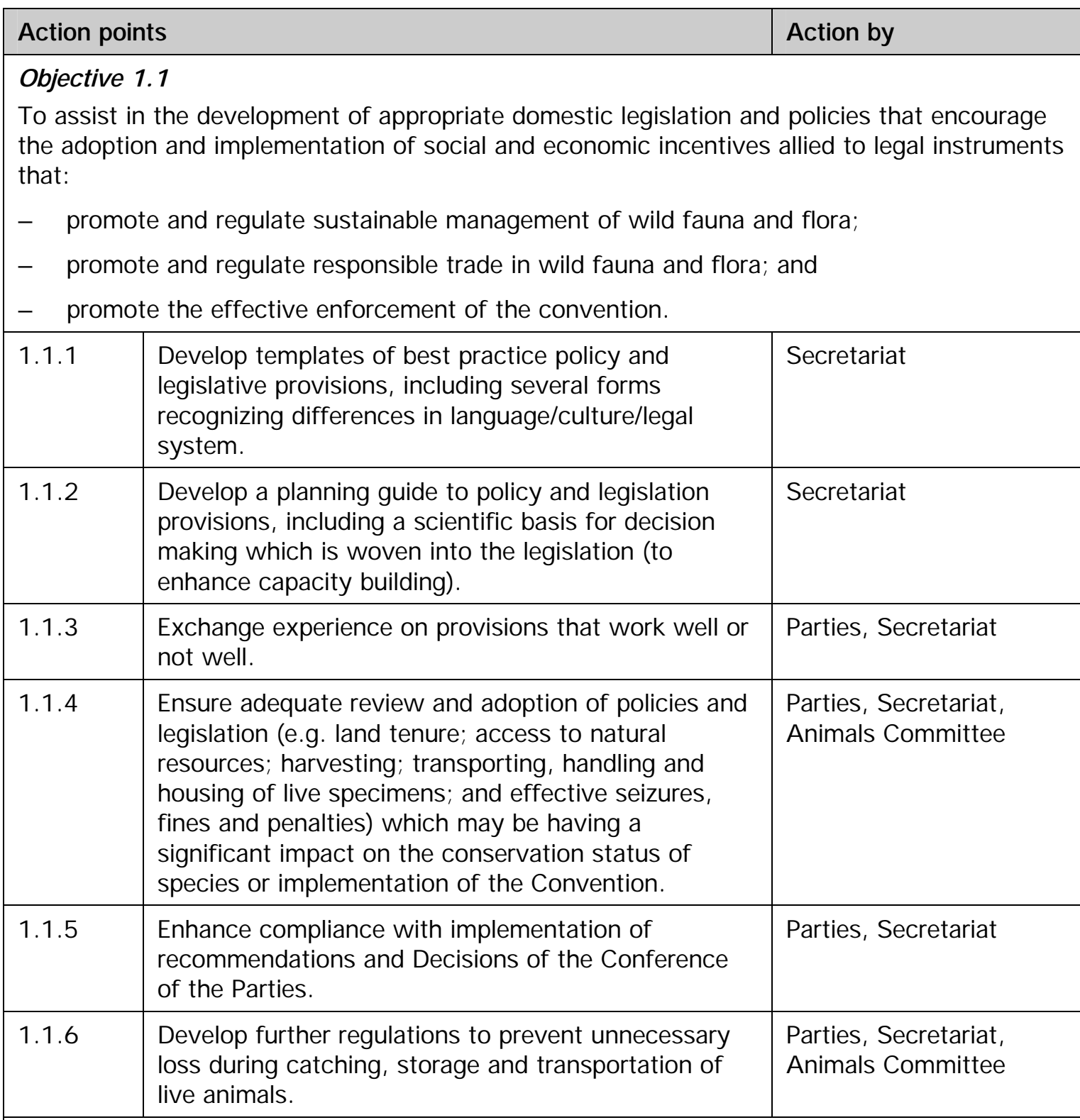

\section{Objective 1.2}

To strengthen the administrative, management and scientific capacity of Parties by improving the coordination between Management and Scientific Authorities and other national agencies responsible for wild animals and plants.

\begin{tabular}{|l|l|l|}
\hline 1.2 .1 & $\begin{array}{l}\text { Convene regional and within-Party workshops to } \\
\text { identify functional roles and train all levels of } \\
\text { administration and related agencies. }\end{array}$ & Parties, Secretariat \\
\hline 1.2 .2 & $\begin{array}{l}\text { Develop a national directory of government officials } \\
\text { responsible for CITES issues. }\end{array}$ & Parties \\
\hline 1.2 .3 & $\begin{array}{l}\text { Improve coordination between Scientific Authorities } \\
\text { and other agencies (e.g. universities, museums) to } \\
\text { maximize transfer of knowledge and skills. }\end{array}$ & $\begin{array}{l}\text { Scientific Authorities, } \\
\text { Secretariat }\end{array}$ \\
\hline
\end{tabular}




\begin{tabular}{|l|l|l|}
\hline \multicolumn{2}{|l|}{ Action points } & Action by \\
\hline 1.2 .4 & $\begin{array}{l}\text { Collate and make accessible lists of specialists } \\
\text { (national and regional). }\end{array}$ & $\begin{array}{l}\text { Scientific and } \\
\text { Management Authorities }\end{array}$ \\
\hline
\end{tabular}

\section{Objective 1.3}

To strengthen the enforcement capacity of the Parties and to improve coordination among Management Authorities and other agencies (e.g. Police, Customs and veterinary and phytosanitary services).

\begin{tabular}{|l|l|l|}
\hline 1.3.1 & $\begin{array}{l}\text { Convene regional and within-Party w orkshops to } \\
\text { identify functional roles and train all levels of } \\
\text { administration and related agencies responsible for } \\
\text { CITES enforcement. }\end{array}$ & Parties, Secretariat \\
\hline 1.3 .2 & $\begin{array}{l}\text { Produce modular procedural manuals pertaining to } \\
\text { enforcement that can be customized for national and } \\
\text { regional differences. }\end{array}$ & Parties, Secretariat \\
\hline 1.3 .3 & $\begin{array}{l}\text { Develop a national directory of government officials } \\
\text { responsible for CITES enforcement issues. }\end{array}$ & Parties \\
\hline 1.3 .4 & $\begin{array}{l}\text { Collate and make accessible lists of taxonomic, } \\
\text { forensic and identification experts. }\end{array}$ & $\begin{array}{l}\text { Scientific and } \\
\text { Management Authorities }\end{array}$ \\
\hline 1.3 .5 & $\begin{array}{l}\text { Identify focal points in agencies (e.g. Police, } \\
\text { Customs, veterinary and phytosanitary services) } \\
\text { responsible for assisting CITES enforcement. }\end{array}$ & Parties \\
\hline 1.3 .6 & $\begin{array}{l}\text { Provide training for staffs of enforcement agencies, } \\
\text { and improve the distribution of existing public } \\
\text { aw areness tools for enforcement purposes. }\end{array}$ & Parties \\
\hline Objective 1.4 & \\
\hline
\end{tabular}

\section{Objective 1.4}

To facilitate development and use of appropriate technologies and information management systems that enhance and expedite the collection, submission and exchange of accurate information.

\begin{tabular}{|l|l|l|}
\hline 1.4 .1 & $\begin{array}{l}\text { On the basis of information from Parties, evaluate } \\
\text { needs, capabilities and opportunities related to } \\
\text { information technologies and management. }\end{array}$ & $\begin{array}{l}\text { Secretariat, with three } \\
\text { permanent Committees }\end{array}$ \\
\hline 1.4 .2 & $\begin{array}{l}\text { Encourage use of technology such as the Internet } \\
\text { and CD-ROM for data and information exchange and } \\
\text { training. }\end{array}$ & Secretariat, Parties \\
\hline 1.4 .3 & $\begin{array}{l}\text { Develop and implement an information management } \\
\text { strategy and training programmes based on 1.4.1 } \\
\text { and 1.4.2. }\end{array}$ & Secretariat, Parties \\
\hline 1.4 .4 & $\begin{array}{l}\text { Develop a simple guide to the Review of Significant } \\
\text { Trade. }\end{array}$ & $\begin{array}{l}\text { Secretariat, A nimals and } \\
\text { Plants Committees }\end{array}$ \\
\hline 1.4 .5 & $\begin{array}{l}\text { Develop and enhance databases that include } \\
\text { information related to species in trade, CITES } \\
\text { Decisions and procedures. }\end{array}$ & $\begin{array}{l}\text { Secretariat, A nimals and } \\
\text { Plants Committees }\end{array}$ \\
\hline $\begin{array}{l}\text { Objective 1.5 } \\
\text { To encourage organizations capable of supporting the Convention to assist the Secretariat } \\
\text { and Parties in building national information management capacities through training and other } \\
\text { activities, and to facilitate improved access to and management of databases. }\end{array}$ \\
\hline \begin{tabular}{l} 
1.5.1 \\
\hline
\end{tabular} & $\begin{array}{l}\text { On the basis of information from Parties, evaluate } \\
\text { national capacity and training needs. }\end{array}$ & Secretariat \\
\hline
\end{tabular}




\begin{tabular}{|c|c|c|}
\hline \multicolumn{2}{|c|}{ Action points } & \multirow{2}{*}{\begin{tabular}{|l|} 
Action by \\
Secretariat
\end{tabular}} \\
\hline 1.5 .2 & $\begin{array}{l}\text { Identify organizations with potential for assisting in } \\
\text { training and capacity building. }\end{array}$ & \\
\hline 1.5 .3 & $\begin{array}{l}\text { Develop a list of available databases and information } \\
\text { sources consistent with Objective } 1.4 \text {. }\end{array}$ & Secretariat \\
\hline 1.5 .4 & Make relevant databases user-friendly. & Secretariat \\
\hline 1.5 .5 & $\begin{array}{l}\text { Enhance compliance with implementation of } \\
\text { recommendations and Decisions of the Conference } \\
\text { of the Parties. }\end{array}$ & Parties, Secretariat \\
\hline \multicolumn{3}{|c|}{$\begin{array}{l}\text { Objective } \mathbf{1 . 6} \\
\text { To ensure that all Parties have at least one designated Scientific Authority with experts in } \\
\text { wild fauna and flora. }\end{array}$} \\
\hline 1.6 .1 & $\begin{array}{l}\text { Advise and assist Parties in exploring options and } \\
\text { models for establishing Scientific Authorities. }\end{array}$ & Secretariat \\
\hline 1.6 .2 & $\begin{array}{l}\text { Pursue on a regular basis progress tow ard the } \\
\text { designation of Scientific Authorities by all Parties. }\end{array}$ & Secretariat \\
\hline \multicolumn{3}{|c|}{$\begin{array}{l}\text { Objective } 1.7 \\
\text { To improve the coordination between CITES Management and Scientific Authorities, and } \\
\text { increase the effectiveness of the latter. }\end{array}$} \\
\hline 1.7 .1 & $\begin{array}{l}\text { Develop a manual specifying the obligations and } \\
\text { procedures of the Scientific Authorities in order to } \\
\text { encourage the development of specific training } \\
\text { courses for them. }\end{array}$ & $\begin{array}{l}\text { Secretariat with A nimals } \\
\text { and Plants Committees }\end{array}$ \\
\hline 1.7 .2 & $\begin{array}{l}\text { Develop regional directories that list the botanists } \\
\text { and zoologists in each region who are experts in } \\
\text { CITES-listed species. }\end{array}$ & $\begin{array}{l}\text { Plants Committee, } \\
\text { Animals Committee }\end{array}$ \\
\hline 1.7 .3 & $\begin{array}{l}\text { Communicate to the Parties the importance and } \\
\text { advisability of including plants experts within the } \\
\text { structure of the Scientific Authorities. }\end{array}$ & Plants Committee \\
\hline 1.7 .4 & $\begin{array}{l}\text { Facilitate workshops and training programmes in } \\
\text { issuance of non-detriment findings. }\end{array}$ & Secretariat \\
\hline 1.7 .5 & $\begin{array}{l}\text { Ensure that Management Authorities consult with } \\
\text { Scientific Authorities on all permits to be issued that } \\
\text { require Scientific Authority findings, and that those } \\
\text { findings are independent and cannot be overridden. }\end{array}$ & Parties \\
\hline \multicolumn{3}{|c|}{$\begin{array}{l}\text { Objective } \mathbf{1 . 8} \\
\text { To encourage Parties to develop and implement effective management programmes for the } \\
\text { conservation and recovery of species, so that the species will no longer satisfy the criteria for } \\
\text { inclusion in the Appendices. }\end{array}$} \\
\hline 1.8 .1 & $\begin{array}{l}\text { Share experience gained by different countries in } \\
\text { conservation, management and the recovery of } \\
\text { species with other countries. }\end{array}$ & Parties, Secretariat \\
\hline 1.8 .2 & $\begin{array}{l}\text { Promote establishment of effective programmes for } \\
\text { species conservation, management and recovery. }\end{array}$ & Parties, Secretariat \\
\hline 1.8 .3 & $\begin{array}{l}\text { Establish national and regional networked rescue } \\
\text { centres for animals and plants. }\end{array}$ & Parties \\
\hline
\end{tabular}




\begin{tabular}{|c|c|c|}
\hline \multicolumn{2}{|c|}{ Action points } & \multirow{2}{*}{\begin{tabular}{|l} 
Action by \\
Parties
\end{tabular}} \\
\hline 1.8 .4 & $\begin{array}{l}\text { Develop and incorporate scientific baselines in } \\
\text { management plans for traded Appendix-II species, } \\
\text { designed to ensure that any trade is sustainable. }\end{array}$ & \\
\hline 1.8 .5 & $\begin{array}{l}\text { Report biennially on progress related to this } \\
\text { objective. }\end{array}$ & Parties, Secretariat \\
\hline \multicolumn{3}{|c|}{ Objective 1.9} \\
\hline \multicolumn{3}{|c|}{$\begin{array}{l}\text { To encourage the proper funding of CITES implementation and enforcement by Parties, and } \\
\text { the adoption of national mechanisms that have resource users make a greater contribution } t \\
\text { such funding. }\end{array}$} \\
\hline 1.9 .1 & $\begin{array}{l}\text { On the basis of information from Parties, evaluate } \\
\text { existing mechanisms for obtaining funds from } \\
\text { resource users for conservation benefit, and share } \\
\text { this information to encourage other Parties to adopt } \\
\text { such mechanisms. }\end{array}$ & Parties, Secretariat \\
\hline 1.9 .2 & $\begin{array}{l}\text { Ensure adequate funding for necessary research and } \\
\text { investigation on CITES species. }\end{array}$ & Parties \\
\hline \multicolumn{3}{|c|}{ Objective 1.10} \\
\hline \multicolumn{3}{|c|}{$\begin{array}{l}\text { To use fully the potential of regional coordination and collaboration in capacity-building } \\
\text { efforts. }\end{array}$} \\
\hline 1.10 .1 & $\begin{array}{l}\text { Identify and make available information on existing } \\
\text { regional entities that could be used to assist with } \\
\text { information sharing, capacity building and funding. }\end{array}$ & $\begin{array}{l}\text { Secretariat, Standing } \\
\text { Committee }\end{array}$ \\
\hline 1.10 .2 & $\begin{array}{l}\text { Interact with existing regional netw orks, } \\
\text { organizations and focal points. }\end{array}$ & $\begin{array}{l}\text { Secretariat, Standing } \\
\text { Committee, Parties }\end{array}$ \\
\hline 1.10 .3 & $\begin{array}{l}\text { Ensure that representatives on all committees are } \\
\text { enabled by their Governments to carry out their } \\
\text { responsibilities. }\end{array}$ & Secretariat, Parties \\
\hline \multirow{2}{*}{\multicolumn{3}{|c|}{$\begin{array}{l}\text { Objective } 1.11 \\
\text { To review and simplify, where possible, existing measures, procedures, mechanisms, and } \\
\text { recommendations for the implementation of the Convention. }\end{array}$}} \\
\hline & & \\
\hline 1.11 .1 & $\begin{array}{l}\text { On the basis of information from Parties, identify } \\
\text { those measures, procedures and mechanisms that } \\
\text { would benefit from review and simplification. }\end{array}$ & Parties, Secretariat \\
\hline 1.11 .2 & $\begin{array}{l}\text { Make recommendations on possible review, } \\
\text { modification and consolidation. }\end{array}$ & Secretariat \\
\hline 1.11 .3 & $\begin{array}{l}\text { Continue consolidation process of Resolutions and } \\
\text { recommendations as appropriate. }\end{array}$ & Secretariat \\
\hline 1.11 .4 & $\begin{array}{l}\text { Produce modular procedural manuals for CITES } \\
\text { implementation that can be customized for national } \\
\text { and regional differences. }\end{array}$ & Parties, Secretariat \\
\hline \multicolumn{3}{|c|}{$\begin{array}{l}\text { Objective } \mathbf{1 . 1 2} \\
\text { To ensure equity of the three working languages. }\end{array}$} \\
\hline 1.12 .1 & $\begin{array}{l}\text { Continue to ensure that all meetings of the } \\
\text { permanent Committees are interpreted in all three } \\
\text { w orking languages, and endeavour to ensure that all } \\
\text { documents are made available in all three working } \\
\text { languages. }\end{array}$ & Parties, Secretariat \\
\hline
\end{tabular}




\begin{tabular}{|c|c|c|}
\hline \multicolumn{2}{|c|}{ Action points } & \multirow{2}{*}{\begin{tabular}{|l|} 
Action by \\
Secretariat
\end{tabular}} \\
\hline 1.12 .2 & $\begin{array}{l}\text { Review current translation systems and recommend } \\
\text { cost-effective alternatives to improve efficiency and } \\
\text { cut costs. }\end{array}$ & \\
\hline 1.12 .3 & $\begin{array}{l}\text { Ensure that the three permanent Committees and the } \\
\text { Conference of the Parties do not discuss any } \\
\text { document not made available in advance in all three } \\
\text { languages. }\end{array}$ & $\begin{array}{l}\text { Secretariat, Conference } \\
\text { of the Parties }\end{array}$ \\
\hline \multicolumn{3}{|c|}{$\begin{array}{l}\text { Objective } \mathbf{2 . 1} \\
\text { To ensure that the Convention's A ppendices correctly reflect the conservation and } \\
\text { management needs of species. }\end{array}$} \\
\hline 2.1 .1 & $\begin{array}{l}\text { Ensure periodic review and refinement of the listing } \\
\text { criteria to ensure their applicability to broad } \\
\text { taxonomic groups, scientific validity and utility. }\end{array}$ & Parties \\
\hline 2.1 .2 & $\begin{array}{l}\text { Regularly review the Appendices to ensure that listed } \\
\text { taxa satisfy the relevant criteria. }\end{array}$ & $\begin{array}{l}\text { A nimals and Plants } \\
\text { Committees }\end{array}$ \\
\hline 2.1 .3 & $\begin{array}{l}\text { Continue the Review of Significant Trade as initiated } \\
\text { by the Parties in Resolution Conf. } 8.9(\text { Rev. })^{1} \text {. }\end{array}$ & $\begin{array}{l}\text { A nimals and Plants } \\
\text { Committees }\end{array}$ \\
\hline 2.1 .4 & $\begin{array}{l}\text { Evaluate trade and biological information on currently } \\
\text { unlisted species subject to significant international } \\
\text { trade to determine whether they w ould qualify for } \\
\text { and benefit from CITES listing. }\end{array}$ & $\begin{array}{l}\text { A nimals and Plants } \\
\text { Committees }\end{array}$ \\
\hline \multicolumn{3}{|c|}{$\begin{array}{l}\text { Objective } \mathbf{2 . 2} \\
\text { To ensure that decisions to amend the Convention's Appendices are founded on sound and } \\
\text { relevant scientific information and meet agreed biological and trade criteria for such } \\
\text { amendments. }\end{array}$} \\
\hline 2.2 .1 & $\begin{array}{l}\text { All proposals to amend the Appendices should } \\
\text { conform to the relevant criteria. }\end{array}$ & Parties \\
\hline 2.2 .2 & $\begin{array}{l}\text { Encourage Parties to consult with the Animals and } \\
\text { Plants Committees as appropriate to assist in the } \\
\text { preparation of proposals to amend the Appendices. }\end{array}$ & $\begin{array}{l}\text { Secretariat, A nimals and } \\
\text { Plants Committees }\end{array}$ \\
\hline 2.2 .3 & $\begin{array}{l}\text { For identified commodities, develop standardized } \\
\text { units of measure for permits, trade analysis and } \\
\text { reporting. }\end{array}$ & $\begin{array}{l}\text { Secretariat, Animals and } \\
\text { Plants Committees }\end{array}$ \\
\hline 2.2 .4 & $\begin{array}{l}\text { Encourage the analysis of annual report information } \\
\text { in the development of proposals to amend the } \\
\text { A ppendices. }\end{array}$ & Parties, Secretariat \\
\hline \multicolumn{3}{|c|}{$\begin{array}{l}\text { Objective } \mathbf{2 . 3} \\
\text { To improve the }\end{array}$} \\
\hline 2.3 .1 & $\begin{array}{l}\text { Develop practical guidance for making non-detriment } \\
\text { findings, including a manual and checklist, and } \\
\text { samples of non-detriment findings and case studies. }\end{array}$ & $\begin{array}{l}\text { Secretariat with A nimals } \\
\text { and Plants Committees }\end{array}$ \\
\hline 2.3 .2 & $\begin{array}{l}\text { Facilitate national and regional training for Scientific } \\
\text { Authorities in the issuance of scientifically based } \\
\text { non-detriment findings; include the use of the } \\
\text { aforementioned guidance on non-detriment findings. }\end{array}$ & $\begin{array}{l}\text { Secretariat with A nimals } \\
\text { and Plants Committees }\end{array}$ \\
\hline
\end{tabular}

1 Replaced by Resolution Conf. 12.8 (Rev. CoP13). 


\begin{tabular}{|c|c|c|}
\hline \multicolumn{2}{|c|}{ Action points } & \multirow{2}{*}{\begin{tabular}{|l|} 
Action by \\
Parties
\end{tabular}} \\
\hline 2.3 .3 & $\begin{array}{l}\text { Ensure that the necessary scientific information is } \\
\text { taken into consideration when making non-detriment } \\
\text { findings (e.g. life history, ecological adaptability, } \\
\text { distribution, abundance, population trends and } \\
\text { management programme). }\end{array}$ & \\
\hline 2.3 .4 & $\begin{array}{l}\text { Ensure that management plans involve periodic } \\
\text { research, monitoring, testing, evaluation and } \\
\text { opportunities for improvement (including adaptive } \\
\text { management). }\end{array}$ & Parties \\
\hline 2.3 .5 & $\begin{array}{l}\text { Provide opportunities for Scientific Authorities to } \\
\text { exchange information and data (e.g. sharing of non- } \\
\text { detriment findings; sharing of data, management } \\
\text { plans and case studies; postings to a website; and } \\
\text { communication through a listserver). }\end{array}$ & $\begin{array}{l}\text { Parties, Secretariat, } \\
\text { Animals and Plants } \\
\text { Committees }\end{array}$ \\
\hline \multicolumn{3}{|c|}{ Objective 2.4} \\
\hline \multicolumn{3}{|c|}{$\begin{array}{l}\text { To develop innovative technologies and encourage relevant research, including research into } \\
\text { CITES implementation and enforcement, and to pursue these objectives, where appropriate, } \\
\text { at the regional level. }\end{array}$} \\
\hline 2.4 .1 & $\begin{array}{l}\text { In collaboration with enforcement agencies, identify } \\
\text { the needs for and potential benefits of innovative } \\
\text { technologies. }\end{array}$ & $\begin{array}{l}\text { Secretariat, A nimals and } \\
\text { Plants Committees, } \\
\text { Parties }\end{array}$ \\
\hline 2.4 .2 & $\begin{array}{l}\text { In collaboration with Parties, international agencies, } \\
\text { and relevant research entities, identify the available } \\
\text { technologies (e.g. digital technology, microchips, } \\
\text { barcodes, holograms, DNA testing) relevant to } \\
\text { assisting the better implementation of the } \\
\text { Convention. }\end{array}$ & $\begin{array}{l}\text { Secretariat, A nimals and } \\
\text { Plants Committees }\end{array}$ \\
\hline 2.4 .3 & $\begin{array}{l}\text { Encourage the adoption and use of such technologies } \\
\text { in CITES processes and procedures (e.g. licensing, } \\
\text { verification, enforcement, communication). }\end{array}$ & Secretariat, Parties \\
\hline 2.4 .4 & $\begin{array}{l}\text { Develop with relevant institutions collaborative } \\
\text { research projects for testing the appropriateness of } \\
\text { new and forthcoming technologies. }\end{array}$ & $\begin{array}{l}\text { Secretariat, A nimals and } \\
\text { Plants Committees }\end{array}$ \\
\hline 2.4 .5 & Assess progress on a regional basis. & $\begin{array}{l}\text { Standing, Animals and } \\
\text { Plants Committees }\end{array}$ \\
\hline \multicolumn{3}{|c|}{$\begin{array}{l}\text { To promote a high degree of cooperation, coordination and collaboration between national } \\
\text { and international law enforcement agencies. }\end{array}$} \\
\hline 3.1 .1 & $\begin{array}{l}\text { Establish, communicate and agree on international } \\
\text { priorities for enforcement. }\end{array}$ & Parties, Secretariat \\
\hline 3.1 .2 & $\begin{array}{l}\text { Encourage each enforcement agency to identify } \\
\text { suitable contacts for WCO, Interpol, and other } \\
\text { relevant international enforcement entities. }\end{array}$ & Parties \\
\hline 3.1 .3 & $\begin{array}{l}\text { Share information on illegal trade, seizures and } \\
\text { ongoing investigations with other relevant Parties. }\end{array}$ & Parties \\
\hline 3.1 .4 & $\begin{array}{l}\text { Liaise with Interpol and WCO working groups on } \\
\text { environmental crime. }\end{array}$ & Parties, Secretariat \\
\hline
\end{tabular}




\section{Objective 3.2}

To stimulate and participate in bilateral, regional and global efforts to combat illegal trade in wild fauna and flora.

\begin{tabular}{|l|l|l|}
\hline 3.2 .1 & $\begin{array}{l}\text { Develop and expand effective regional cooperative } \\
\text { efforts, particularly among countries with common } \\
\text { borders. }\end{array}$ & Parties, Secretariat \\
\hline 3.2 .2 & $\begin{array}{l}\text { Initiate and expand regional enforcement contact } \\
\text { netw orks. }\end{array}$ & Parties \\
\hline 3.2 .3 & Convene regional enforcement training workshops. & Parties, Secretariat \\
\hline 3.2 .4 & Facilitate exchange of intelligence information. & Parties, Secretariat \\
\hline 3.2 .5 & $\begin{array}{l}\text { Formally recognize and aw ard exemplary } \\
\text { enforcement actions. }\end{array}$ & Parties, Secretariat \\
\hline
\end{tabular}

\section{Objective 3.3}

To encourage mutual technical assistance, including the exchange of information, in enforcement matters.

\begin{tabular}{|l|l|l|}
\hline 3.3.1 & $\begin{array}{l}\text { Encourage enforcement agencies to share technology } \\
\text { (e.g. forensic). }\end{array}$ & Parties \\
\hline 3.3.2 & $\begin{array}{l}\text { Collaborate in the production of pertinent } \\
\text { identification materials. }\end{array}$ & Parties, Secretariat \\
\hline 3.3.3 & $\begin{array}{l}\text { Promote development of new technologies for the } \\
\text { identification of specimens in trade. }\end{array}$ & Parties, Secretariat \\
\hline
\end{tabular}

\section{Objective 3.4}

To develop appropriate management strategies and incentives for promoting a change from illegal to legal use of wild fauna and flora.

\begin{tabular}{|l|l|l|}
\hline 3.4 .1 & $\begin{array}{l}\text { Develop and implement appropriate economic, } \\
\text { education, and aw areness programmes that lead to } \\
\text { greater local involvement in wildlife management, } \\
\text { and stimulate participation in combating illegal trade } \\
\text { within and from producer countries. }\end{array}$ & Parties \\
\hline 3.4 .2 & $\begin{array}{l}\text { Develop and implement targeted aw areness } \\
\text { programmes that promote voluntary compliance with } \\
\text { wildlife trade regulations by user groups in consumer } \\
\text { countries. }\end{array}$ & Parties \\
\hline 3.4.3 & $\begin{array}{l}\text { On the basis of information from Parties, develop } \\
\text { templates of best practice in regard to the strategies } \\
\text { and incentives concerned, and encourage Parties to } \\
\text { adopt them. }\end{array}$ & Secretariat \\
\hline $\begin{array}{l}\text { Objective 3.5 } \\
\text { To promote awareness of CiTES issues and a greater understanding by the judiciary of the } \\
\text { social and economic significance of conservation threats posed by illegal trade in wild fauna } \\
\text { and flora. }\end{array}$ & $\begin{array}{l}\text { Contribute papers and articles to law journals and } \\
\text { other publications. }\end{array}$ & Parties, Secretariat \\
\hline 3.5.1 & Attend and contribute to legal conferences. & Parties, Secretariat \\
\hline 3.5.2 & $\begin{array}{l}\text { Provide training to raise aw areness of judges and } \\
\text { prosecutors. }\end{array}$ & Parties, Secretariat \\
\hline 3.5.3 &
\end{tabular}




\begin{tabular}{|c|c|c|}
\hline \multicolumn{2}{|c|}{ Action points } & \multirow{2}{*}{\begin{tabular}{|l} 
Action by \\
Parties, Secretariat
\end{tabular}} \\
\hline 3.5 .4 & $\begin{array}{l}\text { Encourage the judiciary to apply more appropriate } \\
\text { penalties when dealing with wildlife crime. }\end{array}$ & \\
\hline \multicolumn{3}{|c|}{ Objective 4.1} \\
\hline 4.1 .1 & $\begin{array}{l}\text { Recognize the significant contributions of NGOs to } \\
\text { CITES process and encourage greater NGO } \\
\text { participation in CITES outreach. }\end{array}$ & Parties, Secretariat \\
\hline 4.1 .2 & $\begin{array}{l}\text { Encourage Parties to enhance communication and } \\
\text { collaboration with local and national NGOs. }\end{array}$ & Secretariat \\
\hline 4.1 .3 & $\begin{array}{l}\text { Improve availability of CITES information to a broad } \\
\text { spectrum of NGOs. }\end{array}$ & Parties, Secretariat \\
\hline 4.1 .4 & $\begin{array}{l}\text { Collaborate with NGOs in public education and } \\
\text { outreach campaigns. }\end{array}$ & Parties, Secretariat \\
\hline 4.1 .5 & Meet regularly with local and national NGOs. & Parties \\
\hline 4.1 .6 & Meet regularly with international NGOs. & Secretariat \\
\hline \multicolumn{3}{|c|}{$\begin{array}{l}\text { Objective } 4.2 \\
\text { To strengthen }\end{array}$} \\
\hline 4.2 .1 & Identify audiences to be targeted and their needs. & Parties, Secretariat \\
\hline 4.2 .2 & $\begin{array}{l}\text { Develop campaigns and materials for the distribution } \\
\text { of information to targeted groups, with a specific } \\
\text { focus on A ppendix II. }\end{array}$ & Parties, Secretariat \\
\hline 4.2 .3 & $\begin{array}{l}\text { Promote awareness of the impacts of consumption } \\
\text { patterns and demands on species conservation. }\end{array}$ & Parties, Secretariat \\
\hline 4.2 .4 & $\begin{array}{l}\text { Meet regularly with targeted groups and encourage } \\
\text { their active participation. }\end{array}$ & Parties, Secretariat \\
\hline \multicolumn{3}{|c|}{ Objective 4.3} \\
\hline 4.3 .1 & $\begin{array}{l}\text { Identify audiences to be targeted within the scientific } \\
\text { community (e.g. specialist groups, universities, } \\
\text { scientific societies, museums, academic institutions). }\end{array}$ & Parties, Secretariat \\
\hline 4.3 .2 & $\begin{array}{l}\text { Participate actively at scientific meetings and } \\
\text { conferences, and encourage participation in CITES } \\
\text { issues by the scientific community. }\end{array}$ & $\begin{array}{l}\text { Secretariat, Scientific } \\
\text { Authorities, A nimals and } \\
\text { Plants Committees }\end{array}$ \\
\hline 4.3 .3 & $\begin{array}{l}\text { Encourage the scientific community to focus their } \\
\text { efforts on national CITES priorities. }\end{array}$ & Parties \\
\hline \multicolumn{3}{|c|}{$\begin{array}{l}\text { To produce and disseminate informative materials to a broad public at a local, national and } \\
\text { regional levels. }\end{array}$} \\
\hline 4.4 .1 & $\begin{array}{l}\text { Develop information that is culturally and locally } \\
\text { relevant, as w ell as technically accurate. }\end{array}$ & Parties, Secretariat \\
\hline \multicolumn{3}{|c|}{$\begin{array}{l}\text { Objective } 4.5 \\
\text { To improve communication and collaboration with the media. }\end{array}$} \\
\hline 4.5 .1 & $\begin{array}{l}\text { Inform media about CITES-related activities and its } \\
\text { regional and global achievements. }\end{array}$ & Parties, Secretariat \\
\hline
\end{tabular}




\begin{tabular}{|l|l|l|}
\hline \multicolumn{2}{|l|}{ Action points } & Action by \\
\hline 4.5 .2 & $\begin{array}{l}\text { Identify national media outlets and contacts for } \\
\text { dissemination of CITES information. }\end{array}$ & Parties, Secretariat \\
\hline 4.5 .3 & $\begin{array}{l}\text { Develop factual media packets on relevant CITES } \\
\text { issues (e.g. fact sheets, CD-ROMs, videos). }\end{array}$ & Parties, Secretariat \\
\hline
\end{tabular}

\section{Objective 4.6}

To strengthen know ledge, promote aw areness and facilitate enforcement of flora issues in CITES.

\begin{tabular}{|l|l|l|}
\hline 4.6.1 & $\begin{array}{l}\text { Ensure that adequate attention is given to plant } \\
\text { conservation in all activities related to the } \\
\text { implementation of this Plan. }\end{array}$ & Parties, Secretariat \\
\hline
\end{tabular}

\section{Objective 5.1}

To ensure an optimal working relationship with UNEP, as w ell as close coordination and synergy with CBD and other relevant multilateral environmental agreements.

\begin{tabular}{|l|l|l|}
\hline 5.1 .1 & $\begin{array}{l}\text { Enhance national liaison betw een CITES and national } \\
\text { MEA focal points. }\end{array}$ & Parties \\
\hline 5.1 .2 & $\begin{array}{l}\text { Enhance regional and international liaison between } \\
\text { CITES and MEA focal points. }\end{array}$ & Parties, Secretariat \\
\hline 5.1 .3 & $\begin{array}{l}\text { Develop and implement joint projects with other } \\
\text { MEAs (e.g. capacity building, trade controls, } \\
\text { enforcement, scientific and technical coordination, } \\
\text { project development and implementation). }\end{array}$ & Parties, Secretariat \\
\hline
\end{tabular}

\section{Objective 5.2}

To ensure close cooperation and coordination with related conventions, agreements and associations.

\begin{tabular}{|l|l|l|}
\hline 5.2 .1 & $\begin{array}{l}\text { Develop a mechanism to ensure transfer and } \\
\text { exchange of information betw een CITES and relevant } \\
\text { conventions, agreements and associations for } \\
\text { species of concern. }\end{array}$ & Parties, Secretariat \\
\hline 5.2 .2 & $\begin{array}{l}\text { Consider the criteria and decisions of other } \\
\text { Conventions, agreements and associations when } \\
\text { considering the proposals to amend the Appendices, } \\
\text { draft resolutions and decisions. }\end{array}$ & Parties, Secretariat \\
\hline 5.2 .3 & $\begin{array}{l}\text { Encourage other Conventions, agreements and } \\
\text { associations, when making their decisions, to } \\
\text { consider the criteria designed and Decisions made by } \\
\text { CITES Parties. }\end{array}$ & Parties, Secretariat \\
\hline $\begin{array}{l}\text { Objective 5.3 } \\
\text { To ensure greater coordination of scientific and technical programmes and, where } \\
\text { appropriate, more efficient distribution of responsibilities with relevant technical partners such } \\
\text { as IUCN, UNEP-WCMC, TRAFFIC and others. }\end{array}$ & $\begin{array}{l}\text { Identify responsibilities of relevant technical partners } \\
\text { and ensure adequate coordination and mutual } \\
\text { awareness of w ork programmes to avoid duplication. }\end{array}$ & Parties, Secretariat \\
\hline 5.3 .1 & $\begin{array}{l}\text { Develop mechanisms to disseminate information to } \\
\text { Parties on actions of relevant technical partners and } \\
\text { furtherance of the Convention. }\end{array}$ & Secretariat \\
\hline 5.3 .2 & $\begin{array}{l}\text { Inform Secretariat of Parties' projects with technical } \\
\text { partners. }\end{array}$ & Parties \\
\hline 5.3 .3
\end{tabular}




\begin{tabular}{|l|l|l|}
\hline \multicolumn{2}{|l|}{ Action points } & Action by \\
\hline $\begin{array}{l}\text { Objective } \mathbf{5 . 4} \\
\text { To ensure continuing recognition and acceptance of CITES measures by WTO and to ensure } \\
\text { the 'mutual supportiveness' of the decision-making processes between these bodies. }\end{array}$ \\
\hline 5.4 .1 & $\begin{array}{l}\text { Enhance national liaison between CITES and WTO } \\
\text { focal points. }\end{array}$ & Parties \\
\hline 5.4 .2 & $\begin{array}{l}\text { Enhance regional and international liaison between } \\
\text { CITES and WTO. }\end{array}$ & Secretariat \\
\hline
\end{tabular}

\section{Objective 6.1}

To secure at least 20 more Parties to the Convention by 2005 with a special focus on range countries of species subject to significant trade and important consumer countries of wild plants and animals, as well as countries located in regions with relatively low representation.

\begin{tabular}{|l|l|l|}
\hline 6.1 .1 & $\begin{array}{l}\text { Identify priority non-Party countries and pursue their } \\
\text { accession. }\end{array}$ & Secretariat \\
\hline 6.1 .2 & $\begin{array}{l}\text { Engage in bilateral discussions with non-Parties to } \\
\text { encourage their accession and adoption of } \\
\text { appropriate implementing legislation. }\end{array}$ & Parties, Secretariat \\
\hline
\end{tabular}

\section{Objective 6.2}

To encourage acceptance of the 1983 Amendment to Article XXI of the Convention and the subsequent accession by eligible regional economic integration organizations.

\begin{tabular}{|l|l|l|}
\hline 6.2.1 & $\begin{array}{l}\text { Identify which additional countries are needed to } \\
\text { accept the 1983 Amendment to Article XXI, so that } \\
\text { it can enter into force. }\end{array}$ & Secretariat \\
\hline 6.2 .2 & Meet with appropriate officials of those countries. & $\begin{array}{l}\text { Secretariat, relevant } \\
\text { Parties }\end{array}$ \\
\hline
\end{tabular}

\section{Objective 7.1}

To resolve the problem of late and inadequate contributions to the CITES Trust Fund.

\begin{tabular}{|l|l|l|}
\hline 7.1 .1 & $\begin{array}{l}\text { A nalyse the budgeting process of the Secretariat in } \\
\text { context of budgeting and financial management of } \\
\text { different countries and pursue appropriate remedies } \\
\text { (e.g. computation of financial year, dealing with } \\
\text { currency conversion). }\end{array}$ & $\begin{array}{l}\text { Standing Committee, } \\
\text { Secretariat }\end{array}$ \\
\hline 7.1 .2 & $\begin{array}{l}\text { Encourage Parties to pay their contributions in a } \\
\text { timely manner. }\end{array}$ & Secretariat \\
\hline 7.1 .3 & $\begin{array}{l}\text { Recommend incentives and remedies to ensure } \\
\text { payment of contributions. }\end{array}$ & $\begin{array}{l}\text { Standing Committee, } \\
\text { Secretariat }\end{array}$ \\
\hline
\end{tabular}

\section{Objective 7.2}

To ensure that the decisions of the Conference of the Parties take full account of financial implications for the CITES Trust Fund.

\begin{tabular}{|l|l|l|}
\hline 7.2.1 & $\begin{array}{l}\text { Ensure that the work programmes of meetings of the } \\
\text { Conference of the Parties are designed to consider } \\
\text { the financial implications of all decisions prior to } \\
\text { adopting a final budget. }\end{array}$ & Parties, Secretariat \\
\hline 7.2 .2 & $\begin{array}{l}\text { Comply with relevant Resolutions requesting } \\
\text { information on budgetary implications when } \\
\text { presenting proposals and draft resolutions to the } \\
\text { Conference of the Parties. }\end{array}$ & Parties, Secretariat \\
\hline
\end{tabular}




\begin{tabular}{|c|c|c|}
\hline \multicolumn{2}{|c|}{ Action points } & \multirow{2}{*}{\begin{tabular}{|l|} 
Action by \\
Conference of the Parties
\end{tabular}} \\
\hline 7.2 .3 & $\begin{array}{l}\text { Evaluate the budgetary implications for the Trust } \\
\text { Fund and potential for donor funding for proposals } \\
\text { with substantive impact, prior to adoption of such } \\
\text { proposals. }\end{array}$ & \\
\hline 7.2 .4 & $\begin{array}{l}\text { In the budgeting process, identify priorities for } \\
\text { projects and actions under the Trust Fund and for } \\
\text { donor funding. }\end{array}$ & Conference of the Parties \\
\hline \multicolumn{3}{|c|}{$\begin{array}{l}\text { Objective } 7.3 \\
\text { To secure additional funding for actions under the Convention. }\end{array}$} \\
\hline 7.3 .1 & Establish a fund-raising strategy. & Parties, Secretariat \\
\hline 7.3 .2 & $\begin{array}{l}\text { Create a position within the Secretariat that focuses } \\
\text { on acquisition of funding. }\end{array}$ & Parties, Secretariat \\
\hline 7.3 .3 & Encourage development of new funding mechanisms. & Parties, Secretariat \\
\hline 7.3 .4 & Encourage additional voluntary contributions. & Parties, Secretariat \\
\hline 7.3 .5 & $\begin{array}{l}\text { Enhance fund-raising efforts with foundations and } \\
\text { corporations. }\end{array}$ & Parties, Secretariat \\
\hline 7.3 .6 & $\begin{array}{l}\text { Establish funding mechanisms that access funding } \\
\text { from resource users in importing and exporting } \\
\text { countries. }\end{array}$ & $\begin{array}{l}\text { Parties, Secretariat, } \\
\text { Standing Committee }\end{array}$ \\
\hline 7.3 .7 & Develop a marketing strategy for the Convention. & Secretariat \\
\hline \multicolumn{3}{|c|}{$\begin{array}{l}\text { Objective } \mathbf{7 . 4} \\
\text { To encourage additional voluntary contributions and to seek new ways of securing financial } \\
\text { assistance from the donor community. }\end{array}$} \\
\hline 7.4 .1 & $\begin{array}{l}\text { Initiate dialogue through UNEP to explore } \\
\text { mechanisms for accessing Global Environment } \\
\text { Facility (GEF) funding for CITES priorities. }\end{array}$ & Parties, Secretariat \\
\hline 7.4 .2 & $\begin{array}{l}\text { Establish a fund-raising strategy linking with the } \\
\text { strategy in } 7.3 \text {. }\end{array}$ & Parties, Secretariat \\
\hline \multicolumn{3}{|c|}{$\begin{array}{l}\text { Objective } 7.5 \\
\text { To increase the level of realistic planning and forecasting, and to improve financial and } \\
\text { implementation reporting. }\end{array}$} \\
\hline 7.5 .1 & $\begin{array}{l}\text { A nalyse the current budgeting and planning process } \\
\text { to improve forecasting. }\end{array}$ & Parties, Secretariat \\
\hline 7.5 .2 & $\begin{array}{l}\text { Explore opportunities for refining the budgeting } \\
\text { process and presentation to maximize efficiency and } \\
\text { transparency, leading to improved reporting, } \\
\text { decision-making and accountability. }\end{array}$ & $\begin{array}{l}\text { Parties, Secretariat, } \\
\text { Standing Committee }\end{array}$ \\
\hline 7.5 .3 & $\begin{array}{l}\text { Ensure that all meetings of the Standing Committee } \\
\text { include meetings of the Finance Subcommittee. }\end{array}$ & Standing Committee \\
\hline
\end{tabular}




\section{ACTION PLAN FOR THE CONTROL OF TRADE IN AFRICAN ELEPHANT IVORY}

1. All African elephant range States ${ }^{1}$ should urgently:

a) prohibit the unregulated domestic sale of ivory (raw, semi-worked or worked). Legislation should include a provision which places the onus of proof of lawful possession upon any person found in possession of ivory in circumstances from which it can reasonably be inferred that such possession was for the purpose of unauthorized transfer, sale, offer for sale, exchange or export or any person transporting ivory for such purposes;

b) issue instructions to all law enforcement and border control agencies to enforce existing or new legislation rigorously; and

c) engage in public awareness campaigns publicizing existing or new prohibitions on ivory sales.

2. Parties should, by 31 March 2005, report to the Secretariat on progress made. Such reports should include details of seizures, copies of new legislation, copies of administrative instructions or orders to enforcement agencies and details of aw areness campaigns. The Secretariat should report on Parties' progress at the 53rd meeting of the Standing Committee.

3. In the interim, the Secretariat should work with the relevant countries in Africa to provide any technical assistance that may be necessary to aid the implementation of this action plan.

4. The Secretariat should also engage in efforts to publicize the present action plan and the subsequent halting of domestic ivory sales in individual African countries through contacting relevant organizations such as airlines and IATA. It should also, via ICPO-Interpol and the World Customs Organization, communicate with the heads of police and Customs authorities in Africa, advising them of this initiative. Furthermore the Secretariat should request all Parties worldwide to publicize the action plan, particularly to discourage persons who are travelling to Africa from purchasing raw, semi-worked or worked ${ }^{2}$ ivory and to encourage border control authorities to be alert to illegal imports of ivory and to make every effort to intercept illicit movements of ivory.

5. All elephant range States are recommended to cooperate with existing research projects studying the identification of ivory, especially by supplying relevant samples for DNA and other forensic science profiling.

6. The Secretariat should seek the assistance of Governments, international organizations and non-governmental organizations in supporting the work to eradicate illegal exports of ivory from the African continent and the unregulated domestic markets that contribute to illicit trade.

7. At the 13th meeting of the Conference of the Parties, the Secretariat should seek the agreement of the Parties that it would, from $1 \mathrm{~J}$ une 2005, ensure that work is undertaken, including in situ verification missions where appropriate, to assess, on a country-by-country basis, progress made with the implementation of the action plan. Priority should be given to those Parties that are identified during research by the Secretariat and through other appropriate sources of information to have active and unregulated internal markets for ivory. Priority should be given to Cameroon, the Democratic Republic of the Congo, Djibouti, Nigeria and any other country identified through ETIS.

1 Except any Party for which an annotation in the Appendices authorizes trade in worked ivory.

2 Except Parties where the export of worked ivory for non-commercial purposes is lawful. 
8. In cases where Parties or non-Parties are found not to implement the action plan, or where ivory is found to be illegally sold, the Secretariat should issue a Notification to the Parties advising them that the Conference of the Parties recommends that Parties should not engage in commercial trade in specimens of CITES-listed species with the country in question.

9. The Secretariat should continue to monitor all domestic ivory markets outside Africa to ensure that internal controls are adequate and comply with the relevant provisions of Resolution Conf. 10.10 (Rev. CoP12) on Trade in elephant specimens. Priority should be given to China, J apan and Thailand, with particular attention being paid to any Party that has notified the Secretariat that it wishes to authorize imports of ivory for commercial purposes.

10. The Secretariat should report upon the implementation of the action plan at each meeting of the Standing Committee. 


\section{TERMS OF REFERENCE FOR AN EVALUATION OF THE REVIEW OF SIGNIFICANT TRADE}

\section{Objectives}

1. The objectives of the evaluation of the Review of Significant Trade are to:

a) evaluate the contribution of the Review of Significant Trade to the implementation of Article IV, paragraphs 2 (a), 3 and 6 (a);

b) assess the impact over time of the actions taken in the context of the Review of Significant Trade on the trade and conservation status of species selected for review and subject to recommendations, taking into consideration the possible effects of these measures on other CITES-listed species;

c) formulate recommendations in view of the results and findings of the evaluation and the impact assessment; and

d) prepare a document on the evaluation of the Review of Significant Trade and the resulting conclusions and recommendations for consideration at the first appropriate meeting of the Conference of the Parties.

\section{Process}

2. The evaluation will commence immediately after the 14th meeting of the Conference of the Parties, contingent on the availability of sufficient funds to ensure its completion.

3. The A nimals and Plants Committees will oversee the evaluation, which will be administered by the Secretariat. Consultants may be engaged to assist it in this regard.

4. A w orking group composed of members of the A nimals and Plants Committees, Parties, the Secretariat and invited experts will be responsible for advising on the evaluation process, reviewing the findings of associated research and developing recommendations for wider consideration by the Parties.

5. The Secretariat will regularly report on the progress of the evaluation at meetings of the Animals and Plants Committees.

6. A final report, which may include proposed amendments to existing Resolutions or Decisions, or other recommendations, and which will incorporate the comments of the Animals and Plants Committees and of range States addressed in the report, will be submitted by the Chairmen of the Animals and Plants Committees for consideration at a future meeting of the Conference of the Parties. The Chairman of the Animals or Plants Committee may submit an interim report to the Standing Committee when appropriate and considered useful.

\section{Content of the evaluation}

7. The evaluation of the Review of Significant Trade should include the following activities:

a) Assess:

i) the process used to select species for review (including the reliance on numerical data), and the species selected as a result;

ii) the process and means used to compile and review information concerning the implementation of Article IV, paragraphs 2 (a), 3 and 6 (a), for the selected species (including communications with the range States), and the subsequent use of this information by the Animals and Plants Committees for the categorization of species and the issuance of recommendations;

iii) the types and frequency of recommendations made; 
iv) the nature and rate of responses to recommendations, and problems identified;

v) the use of the recommendations by range States as guidance for managing target species and other CITES-listed species w ith similar characteristics;

vi) the nature and scale of the support provided to range States for implementing the recommendations, including field projects, financial aid and assistance in building local capacities;

vii) the ongoing process to monitor and review the implementation of recommendations, having regard to differing points of view as to where this responsibility should lie; and

viii) the impacts of the process on other aspects of CITES implementation, including how problems identified in the course of the review but not directly related to the implementation of Article IV , paragraphs 2 (a), 3 and 6 (a), were addressed.

b) Conduct case studies of a representative range of species and countries subject to recommendations to assess subsequent short- and long-term changes, and whether these could be attributed to the process, in:

i) conservation status of the target taxa in the range States;

ii) trade volumes and patterns of the target taxa, considering trade involving the range States subject to recommendations, other range States and non-range States;

iii) production or management strategies for the target taxa;

iv) market developments of conservation relevance (such as shifts in supply or demand);

v) costs and benefits associated with the management of and trade in the target taxa (such as the effects of trade suspensions and export quotas, shift in trade to nonCITES species or increased illegal trade);

vi) protection status of the target taxa within range States, and regulatory measures outside range States;

vii) trade patterns, conservation status and management for other CITES-listed species that might be suitable 'substitutes' for the target taxa; and

viii) changes in conservation policies in range States.

c) Analyse the information to assess the effectiveness, costs and benefits ${ }^{1}$ of the Review of Significant Trade as implemented so far, by reference to the cost of the process and the time it takes, and identify means to improve the contribution it makes to the objectives of the Convention by reducing the threats to wild species.

1 The phrase 'effectiveness, costs and benefits' is intended to address issues such as whether or not the funds spent on the process give value for money comparable to that for other CITES activities, and whether the time-scale envisaged in the process is too long for species that are in rapid decline. 


\section{QUITO DECLARATION}

The representatives of the Parties to the Convention on International Trade in Endangered Species of Wild Fauna and Flora (CITES) of the Region of Central and South America and the Caribbean, having met in Quito, Ecuador, from 29 February to 2 March 2000;

RECOGNIZING the importance of the Convention as a valuable instrument to protect the species of wild fauna and flora in the region and to guarantee their sustainable use;

CONSIDERING that, from 10 to 20 April 2000, the 11th meeting of the Conference of the Parties to the Convention will be held in Nairobi, Kenya;

\section{CONCLUDE AND RECOMMEND to:}

a) emphasize the need to enhance cooperation amongst neighbouring countries or countries belonging to the same sub-region in order to coordinate the efforts against illegal trade, recognizing that one of the threats that affect wildlife species of the region is the illicit trade;

b) promote, when appropriate, the adoption or enhancement in each country of effective legislation. The purpose of this legislation is to regulate the trade in CITES-listed species and to penalize offenders engaging in illicit activities. To this end, the Parties commit themselves to review their legislation and, if necessary, proceed to its amendment, in order to ensure effective implementation of the Convention;

c) promote the development of exchange programmes to share well-founded scientific information, in order to conserve the species protected under CITES. This information will be compiled by competent regional institutions, with the help, if necessary, of international experts. The Parties recognize that up-to-date and accurate information is essential to arrive at non-detriment findings regarding the survival of species, at the same time recognizing the benefits derived from management plans or pilot projects of an experimental nature;

d) promote capacity-building programmes at a national and regional level, aimed at officials responsible for the implementation of the Convention, at different levels and institutions;

e) promote the creation of a regional fund for the purpose of financing programmes for compilation and exchange of scientific data, population studies and management plans for wild species. The Parties commit themselves to collaborate closely with the CITES Secretariat, as well as with international and regional organizations, in fund-raising activities that will allow then to carry out such studies and programmes;

f) consider regional cooperation as a special priority for the protection of wildlife. For this reason, the Parties commit themselves to strengthening the existing mechanisms of regional cooperation with the purpose of establishing harmonized policies and coordinating mechanisms to carry out activities related to the application within CITES in the region;

g) establish or, where appropriate, improve coordination mechanisms among relevant government agencies. In this sense, the Parties shall endeavour to ensure permanent consultations amongst institutions responsible for the environment, for external trade, for foreign affairs, for agriculture, as well as Customs and Police agencies, the judiciary and other competent authorities; and

h) recommend that all efforts be made to ensure the continuity and periodicity of regional meetings. 
The representatives of the Parties to CITES at the First CITES Regional Meeting for Central and South America and the Caribbean (Quito, March 2000) wish to express their special thanks to the Ecuadorian Government for its important contribution in organizing and hosting this regional meeting, as well as to the CITES Secretariat for its support throughout the whole process. Financial support from the Netherlands and Spain is gratefully acknow ledged.

Adopted in San Francisco de Quito (Ecuador), 2 March 2000, in two identical copies, in Spanish and in English.

\author{
Victoria Lichtschein \\ ARGENTINA
}

Regional Representative
Dimas Botello

PANAMA

Regional Representative
Danilo Silva

ECUADOR

Chairman of the Meeting 